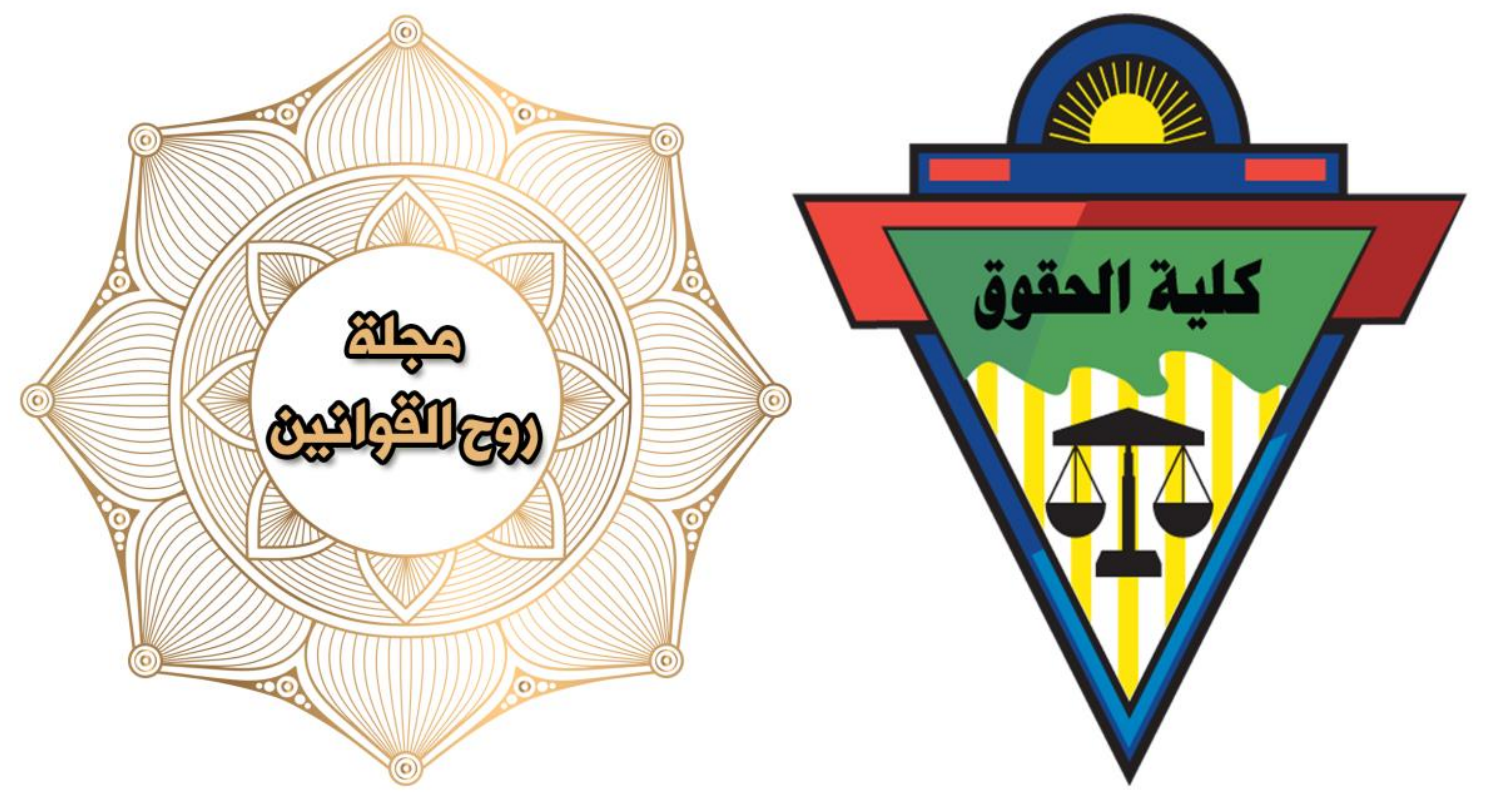

همائة الملكية النكرية في الألهن السيراني

$$
\begin{aligned}
& \text { الدكتوم / عبد المبن سعيد أبوداس }
\end{aligned}
$$

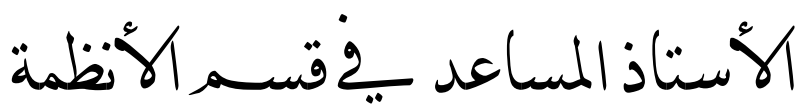

$$
\begin{aligned}
& \text { بكلية العوم الإداريةبكامعنبمان }
\end{aligned}
$$




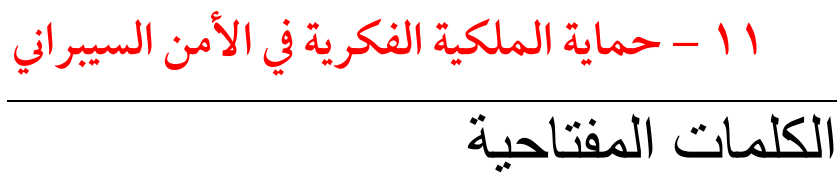

\begin{tabular}{|c|c|}
\hline م ع ماية & \\
\hline Protection & \\
\hline Intellectual property & \\
\hline Cybersecurity & \\
\hline
\end{tabular}




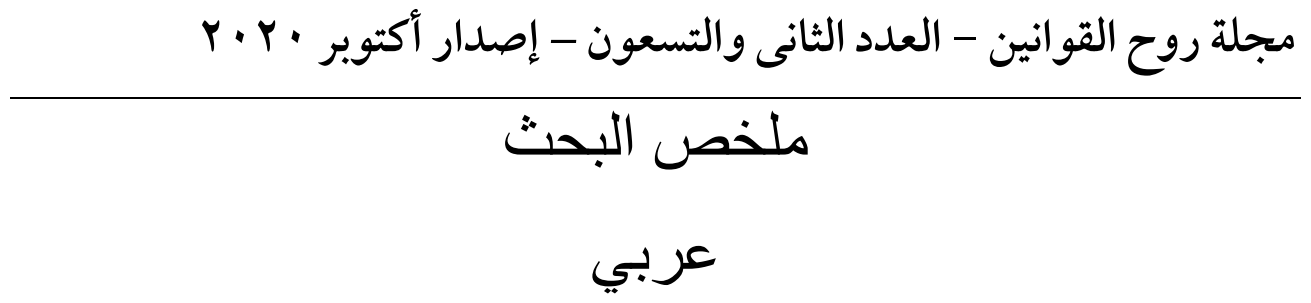

باتت الحاجة ملحة لحماية مجالات الملكية الفكرية في مجال الأمن السيبراني؛ وذلك لتوفير حماية ذات طابع مخصوص للحفاظ على سرية المعلومات بشتى أنواعها ومجالاتما؛ وذلك باتخاذ كافة التدابير لكف أيدي العابثين بما.

وحتى نصل إلى حماية شاملة فلا بد من معرفة جملة تلك التهديدات والاعتداءات على حقوق الملكية الفكرية حتى نستطيع توفير حماية لمجالات الملكية الفكرية، وعليه كان من الضرورة بحث هذا الموضوع والعمل على إيجاد وسائل آمنة ومتجددة من خلال تطوير منظومة أمن الفضاء السيبراين وتفعيل برامج حمايـة الهويـة الرقمية ولا تقف الحماية عند هذه الوسائل الإليكترونية، بل يتعدى الأمر إلى تطوير الاتفاقيات الدولية والتشريعات القانونية لمواكبة التقدم التكنلوجي، حتى نضمن الوقاية من مخاطر الاعتداءات ومهددات الملكية الفكرية في بجال الأمن السيبراين. 
年 - 11 - حماية الملكية الفكرية في الأمن السيبراني

\title{
Intellectual property protection in
}

\section{cybersecurity}

\begin{abstract}
There is an urgent need to protect the intellectual property in cybersecurity in order to provide protection of a special nature to preserve the confidentiality of information of all kinds and fields by taking all measures to stop the hands of those who abuse it.

To reach comprehensive protection, it is necessary to know the totality of those threats and attacks on intellectual property rights so that experts can protect the fields of intellectual property. However, protection does not stop at these electronic means, but rather it goes beyond to develop international agreements and legal legislations to keep pace with technological progress to ensure the prevention from the risks of attacks and threats to intellectual.
\end{abstract}


r. r · مجلة روح القوانين - العدد الثانى والتسعون - إصدار أكتوبر بسم الله الرحمن الرحيم

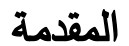

الحمد لله رب العالمين، والصلاة والسلام على أشرف المرسلين، سيدنا محمد

صلى الله عليه وسلم، وعلى آله وصحبه وسلم أجمعين.

تعتبر الملكية الفكرية من الأفكار المستحدثة في الأنظمة الوضعية، لذلك كانت

فكرة حماية المفكر أو المبتِكر لأفكاره ومبتكراته هي فكرة وليدة القرن الماضي، ولم يكن لها وجود في الأزمنة المتقدمة، إذ هي فكرة نشأت كنتيجة طبيعية للتطور الحديث في عالم المعرفة والابتكار، ولذا فقد نشأت هذه الفكرة للى رجال القانون اهتماماً بالغاً، وتلقتها التتظيمات المعاصرة لتؤسس لها مركزاً قانونياً.

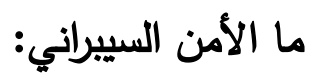
بقصد بالأمن السيبراني: ممارسة حماية الأنظمة والثبكات والبرامج من الهجمات الرقمية. التي تهدف عادةً إلى الوصول إلى المعلومات الحساسة أو تغييرها أو إتلافها أو ابتزاز المال من المستخدمين أو مقاطعة العمليات التجارية.(')

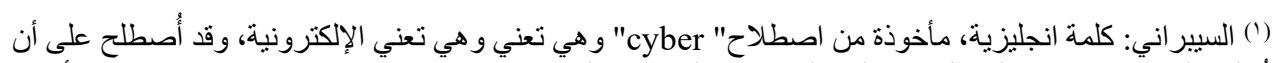

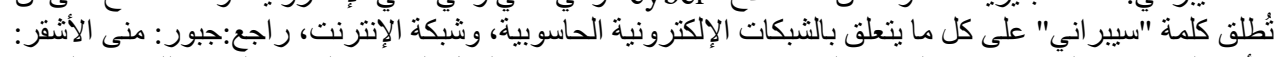

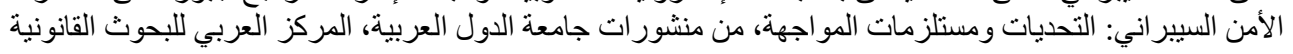


(1) - حماية الملكية الفكرية في الأمن السيبراني

أهمية الموضوع وسبب اختياره:

لما كانت العولمة الإكترونية هي الضرورة الملحة في عالمنا اليوم، إذ لا تستطيع الدول إدارة منظومة أعمالها في شتى أجهزتها الحكومية إلا عن طريق الحواسب والمنصاتالإكترونية، فقد أصبحت المعلومات المتعلقة بالأمن للدول في مسيس الحاجة إلى الحفاظ عليها وحمايتها من الهجمات الإكترونية التي قد تسبب أضراراً بالغة بأمن الدول وسلامة معلوماتها الإكترونية، ومن هنا أصبحت حماية الملكية الفكرية في مجال الفضاء السيبراني من الحاجات الملحة، التي يفرضها واقع المعلومات الأمنية المعاصر. حيث تظهر أهمية حماية الملكية الفكرية في مجال الأمن السييراني من خلال العناصر الآتية: ا. توفير الحماية الفائقة لخصوصية المعلومات والإبقاء على سريتها، وذلك بعدم السماح لغير المخولين بالوصول إليها باستخدامها. r. الحفاظ على المعلومات وسلامتها وتجانسها، وذلك بكف الأيادي من العبث بها. r. تحقيق وفرة البيانات وجاهزيتها عند الحاجةِ إليها. ع. حماية الأجهزة والثبكات ككّل من الاختراقات لتكون درعٌ واقٍ للبيانات والمعلومات.

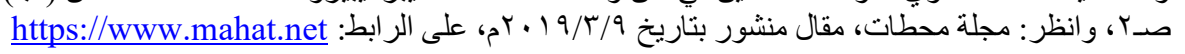


r. r · مجلة روح القوانين - العدد الثانى والتسعون - إصدار أكتوبر

0. استكشاف نقاط الضعف والثغرات في الأنظمة ومعالجتها.

7. استخدام الأدوات الخاصة بالمصادر الدفتوحة وتطويرها لتحقيق مبادئ الأمن

السيبراني.

V- توفير بيئة عمل آمنة جدًا خلال العمل عبر الثبكة العنكبوتية.

لكل ما سابق فقد اخترت هذا الموضوع لبيان المخاطر ووسائل الحماية للملكية الفكرية في مجال الأمن السيبراني.

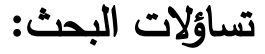
يتحدد سؤال هذا البحث في الآتي:

ما هو الأمن السيبراني، وما هي المخاطر الأمنية التي تهدد الملكية الفكرية في مجال الأمن السيبراني، وما هي الوسائل التي يمكن من خلالها حماية الملكية الفكرية في

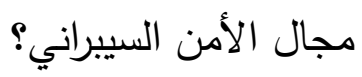
هذا ما سوف يحاول الباحث الإجابة عنه في ثنايا هذا البحث. 
11 - حماية الملكية الفكرية في الأمن السيبراني

هدف البحث:

يهدف هذا البحث إلى التعريف بمفهوم الأمن السيبراني، وبيان المخاطر الأمنية في الفضاء السيبراني، وبيان الوسائل التي يمكن من خلالها حماية الملكية الفكرية في مجال الأمن السيبراني.

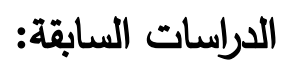

لم أجد حسب اطلاعي دراسة تتحدث عن هذا الموضوع، ولا تتناول جوانبه المختلفة ولا موضوعاته المتفرعة، وإنما هو منشور ومتحدث عنه في عدة مقالات وورقات عمل متناثرة على المواقع الإكترونية، ولم أجد حتى اليوم دراسة وافية قد استوفت هذا الموضوع من شتى جوانبه.

ومن تلك الموضوعات المتناثرة:

ا. الأمن السييراني: التحديات ومستلزمات المواجهة، ورقة عمل أعدتها د. منى الأشقر جبور، وهي من منشورات جامعة الدول العربية، المركز العربي للبحوث القانونية والقضائية، اللقاء السنوي الأول للمختصين في أمن وسلامة الفضاء السيبراني، بيروت

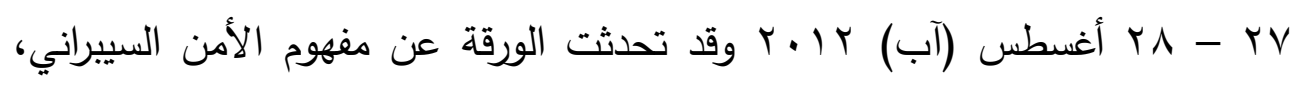
وبعض المخاطر التي تتهدد الأمن السييراني في عبارة مختصرة. 
r. r · مجلة روح القوانين - العدد الثانى والتسعون - إصدار أكتوبر r. أمن المعلومات أحد السبل لحماية الملكية الفكرية، مقال للباحث: ابن ضيف الله فؤاد، منشور بمجلة cybrarians العدد ع ب، ديسمبر • • آم، وقد تحدث فيه الباحث عن أهمية الأمن السيبراني، ونماذج لبعض الجرائم التي ترتكب في مجال الفضاء

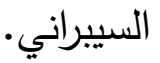

r. عرض موجز لإطار الملكية الفكرية القانوني والتظظيمي في الولايات المتحدة الأمريكية، معلومات أساسية عامة، مقال منشور على موقع: https://wipolex.wipo.int وقد تحدث المقال عن حماية الملكية الفكرية في القانون

$$
\begin{aligned}
& \text { الأمريكي في عناصر مختصرة. } \\
& \text { منهج البحث: }
\end{aligned}
$$

اعتمدت في هذا البحث على المنهج الاستقرائي وذلك من خلال استقراء النصوص التشريعية في مجال حماية المعلومات الإلكترونية في الدول المختلفة كما اعتمدت على المنهج التحليلي، من خلال التأمل والنظر فيما تحتويه هذه النصوص، وذلك للوصول إلى حماية الملكية الفكرية من الجرائم المعلوماتية في مجال الأمن السيبراني.

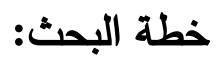
فقد قسمت الحديث حول موضوع هذا البحث إلى مقدمة، وثلاثة مباحث وخاتمة: 
11 - 11

ـ أما المقدمة فقد تحدثت فيها عن أهمية الموضوع وسبب اختياره، والهدف من البحث،

وسؤاله، والدراسات السابقة، ومنهج البحث وخطته.

المبحث الأول:مغهوم الحماية الفكرية في الأمن السييراني

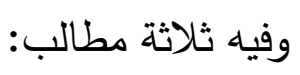

المطلب الأول: مفهوم حماية الملكية الفكرية لغة واصطلاحاً.

المطلب الثاني: مفهوم الأمن السييراني وعناصره. لغة واصطلاحاً

المطلب الثالث: علاقة الأمن السييراني بحقوق الملكية النكرية.

المبحث الثاني: مهددات الملكية الفكرية في الأمن السييراني

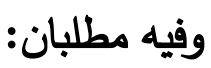

المطلب الأول: الاعتداءات الخاصة بأمن المعلومات وقيتها.

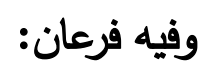

الفرع الأول: الاعتداءات الخاصة بأمن المعلومات المعالجة آلياً.

الفرع الثاني: الاعتداءات الخاصة بقيمة المعلومات المعالجة آلياً

المطلب الثاني: الاعتداءات الخاصة بحقوق الملكية الأدبية والنكرية لبرامج الحاسب

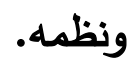

$\left\{\varepsilon r_{0}\right)$ 
r. r · مجلة روح القوانين - العدد الثانى والتسعون - إصدار أكتوبر

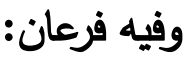

الفرع الأول: الاعتداءات المتعلقة بالنصب والاحتيال في عالم النشر. القرع الثاني: الاعتداءات المتعلقة بالحصول على مال الغير عن طريق الغش المعلوماتي

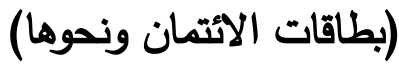
المبحث الثالث: وسائل حماية الملكية الفكرية في الأمن السييراني.

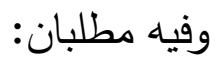
المطلب الأول: وسائل الحماية الإكترونية. المطلب الثاني: وسائل الحماية في التشريعات القانونية

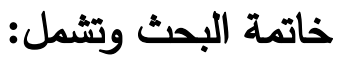

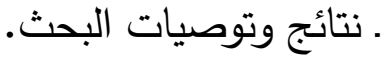

$$
\text { المبحث الأول }
$$

مفهوم حماية الملكية الفكرية في الأمن السيراني

في هذا المبحث سوف أطرح نظرة شاملة حول مفاهيم حماية الملكية الفكرية، حيث سأوضح معاني مصطلحات حماية الملكية الفكرية في اللغة والاصطلاح، كذلك نتعرض 
| 11 - حماية الملكية الفكرية في الأمن السيبراني

لمفهوم الأمن السيبراني مع بيان عناصره، ثم نسلط الضوء على علاقة الأمن السييراني

بحقوق الملكية الفكرية، وهذا كله يتأتى وفقاً للمطالب النالية:

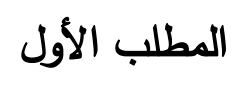

\section{مفهوم حماية الملكية الفكرية لغة واصطلاحاً}

لابد لنا أن نتعرف على مصطلح حماية اللكية الفكرية، حيث أن هذا المصطلح

مكون من ثلاث كلمات ولكل واحد منها معنى مختلف، فالأولى تتعلق بالحماية والثانية

بالملكية والثالثة بالفكرية، ومن هنا كان من الأهم تناول هذه المصطلحات على حدة

لغةً واصطلاحاً ثم نخلص إلى تعريفاً لهذا المصطح مركباً.

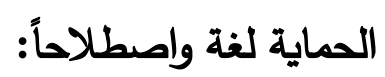

الحماية: مصدر من الفعل حَمَى، فيقال حَمَى الثيء يحميه حَمْياً، وحماية

بالكسر : أي مَنَعَهُ، وحمى المريض ما يضره: منَعَه إياه، واحتمى هو من ذلك وتحمَى:

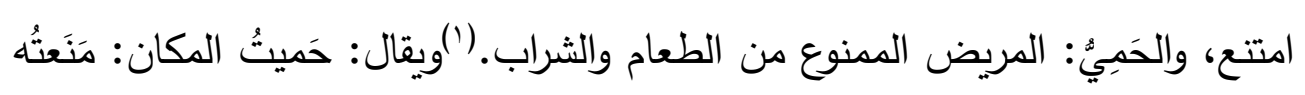




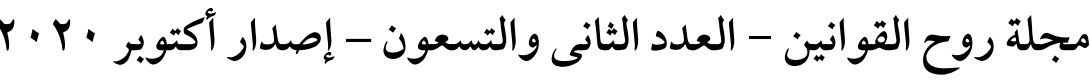
أن يُقرب، واحتمى الرجل من كذا: أي اتقاه.(') وفي الحديث النبوي: (ألا وإن حمى الله

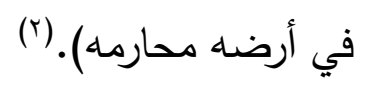

ويقال حَتَى يحْمي، حمياً الرجل الثَيء، ومنه: تَنَعه، ودَفعه عنه -القوم حماية:

$$
\text { أي قام بنصرهم، والمرض حمية: منعه ما يضره.(") }
$$

ويقال: هذا شيء حَمِيٌ؛ أي: محظور لا يقرب، وحَمَيُُه حمايةً: إذا دفعت عنه،

ومنعت منه من يقرَبَهُ، والحمِيُُ: القريبُ المشفقُُ، وسمي بذلك لأنَّهَ يحتُُ حمايةً لذويها،

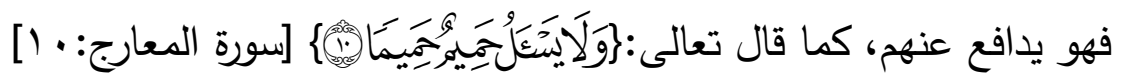

أما معنى الحماية في الاصطلاح يختلف معناه بحسب ما يضاف إليه، فمثلاً حماية المواطنين تعني صيانتهم ووقايتهم، وحماية البيئة تعني منع إصابتها بالتلوث، وحماية المستهلك تعني منع استغلالهم، ويوجد أيضًا حماية الاقتصاد وحماية التجارة وغيرها من الاصطلاحات الكثيرة لهذا الففهوم الواسع.(§)

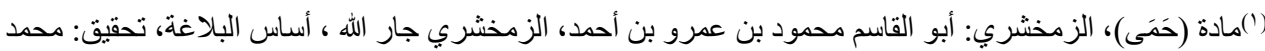

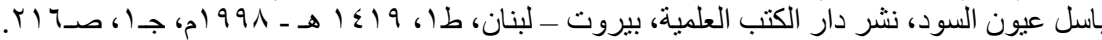

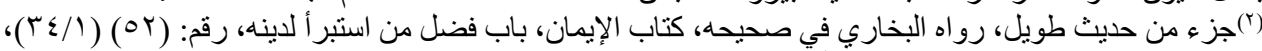

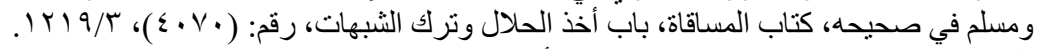

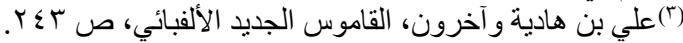

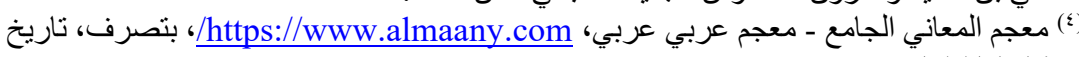


11 - - حماية الملكية الفكرية في الأمن السيبراني

وخلاصة الأمر: يخلص الباحث إلى وجود تناسب بين المعنى اللغوي

والاصطلاحي فصطلح الحماية يدور بين معنى الدنع والدفح، إلا أن لفظ مصطلح

الحماية يختلف معناه بحسب ما يضاف إليه. 
r.r. · مجلة روح القوانين - العدد الثانى والتسعون - إصدار أكتوبر

الملكية لغة واصطلاحاً:

الملكية لغة: مأخوذة من الفعل ملك يملك تملكاً ومملوكاً، والمعنى حيازة الثيء

والاحتواء له، ومن ثم إمكان القدرة على الفعل فيه بالاستبداد والتصرف، فهو مالك

وتملك الشيء امتلكه أو ملكه قهرا.(1)

الملكية في الاصطلاح: لابد من بيان مصطلح الملكية من الجانب الثرعي ومن

جانب شراح القانون المدني، أما ما يتعلق بتعرف مصطلح الملكية من الجانب الثرعي أو بمعنى ما توصل له فقهاء الشريعة الإسلامية.

\section{أولا: تعريف مصطلح الملكية في الشريعة الإسلامية:}

تعددت آراء الفقهاء اتجاه مصطلح الملكية، ويعود سبب هذا التتوع إلى اختلافهم

في ضبط الملك، وما يعتبر مالاً مملوكا، وما لا يعتبر كذلك،(()وجاء في تعريف الملكية بأن الملك "هو الاختصاص بالمحل في حق التصرف، أو شرع للتمكن من التصرف في المحل"(")،وقيل: "الملك حكم شرعي مقدر في العين أو المنفعة، يقتضي تمكن من

(1) ابن منظور : محمد بن مكرم بن على، أبو الفضل، جمال الدين ابن منظور الأنصاري الرويفعى الإفريقى، دار صادر

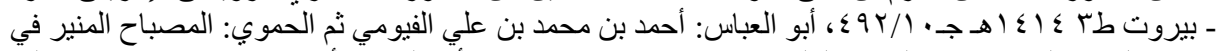

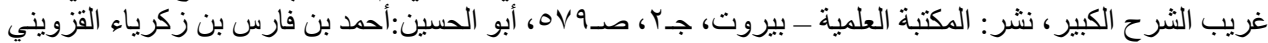

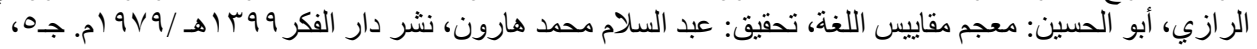

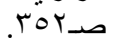
(r) لحرش: أسعد المحاسن: الملكية الفكرية بين تشجيع الابتكار وتحريم الاحتكار ، منشور بموقع

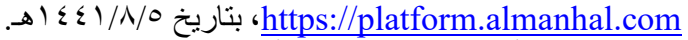

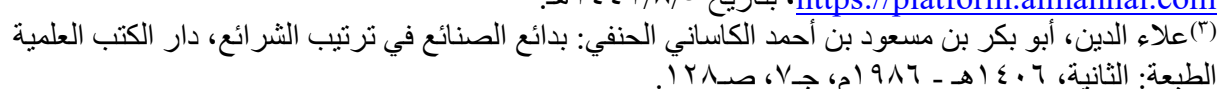
$\leqslant \Gamma$ 
11 - 11

يضاف إليه من انتفاعه بالمملوك، والعوض عنه من حيث هو كذلك"،(()وعرفها القرافي بقوله:" حكم شرعي مقدر في العين أو المنفعة، يقتضي تمكين من يضاف إليه من انتفاعه بالثيء وأخذ العوض عنه من حيث هو كذلك"((')(من المعلوم والذي استقر عليه الفقه الإسلامي أن الحقوق كلها لا تثبت إلا بإثبات الثارع لها وتقريره لأسبابها ومنها حق الملكية وهذا ما نبه عليه القرافي في تعريفه،(ّ) وبعد هذا العرض للتعاريف أجد أن تعريف العبادي يجمع كل المراد إثباتها في تعريف الملك، حيث عرفه بأنه" اختصاص إنسان بشيء يخوله شرعاً الانتفاع والتصرف وحده ابتداءً إلا لمانع".(؛) أولا: تعريف مصطلح الملكية في عند القانونين:

قيل في تعريف الملكية هي: " حق الاستئثار باستعماله وباستغلاله والتصرف فيه

على وجه دائم، وكل ذلك في حدود الثرع"(*)، وبمعنى آخر قيل هي: " اختصاص أو استئثار إنسان بشيء يقتضي له وحده حق استعماله واستغلاله والتصرف فيه ابتداءً إلا

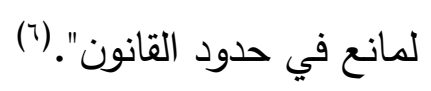

(1) القرافي: أبو العباس شهاب الدين أحمد بن إدريس بن عبد الرحمن المالكي الشهير بالقرافي: أنوار البروق في أنواء

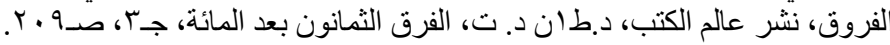

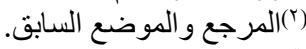

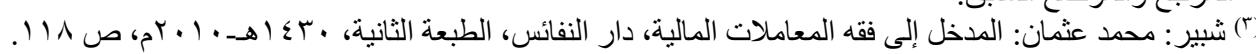

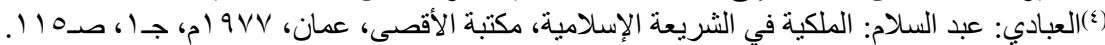

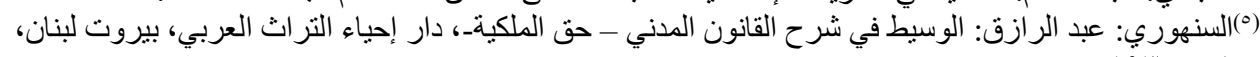

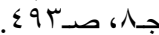

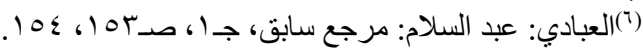




$$
\text { r.r. · مجلة روح القوانين - العدد الثانى والتسعون - إصدار أكتوبر }
$$

وخلاصة الأمر: فملكية الثيء حق كفل الثرع والنظام لصاحبها كل التصرفات

التي ترد على هذا الثيء، كالاستعمال والاستغلال والتصرف فله أن يمارس أي نوع من هذا التصرفات كيف يثاء ولا يمانعه أحد من ذلك؛ إلا ما تم تقيده في الشرع والنظام.

\section{الفكرية لغة واصطلاحاً:}

\section{الفكرية لغة:}

جاءت مادة فكر في معاجم اللغة بمعنى: التَّكَكُرُ أي التأمل، والاسم والفكر والفِكرة

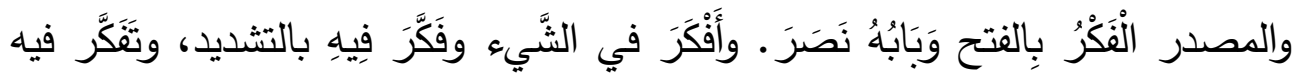

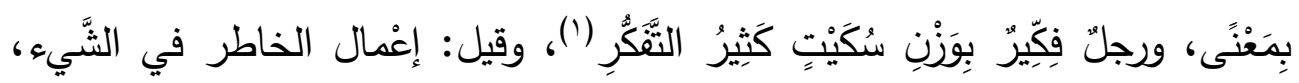
والتدبر والتأمل فيه، وإعمال العقل فيه.(؟)

$$
\text { الفكرية في الاصطلاح: - (اصل }
$$

والفكر اصطلاحاً: هو إعمال العقل في المعلوم للوصول إلى دعرفة المجهول.(r) الملكية الفكرية مصطلح قانوني نتيجةَ ما ينتجه العقل البشري من أفكار ، تتم ترجمتها إلى حقائق ملموسة، فيدخل في نطاقها كافة الحقوق الناتجة من النشاط الفكري

$$
\begin{aligned}
& \text { (1)الر ازي: زين الدين أبو عبد الله محمد بن أبي بكر بن عبد القادر الحنفي: مختار الصحاح، المكتبة العصرية ـ الدار }
\end{aligned}
$$

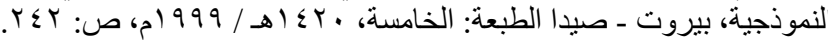

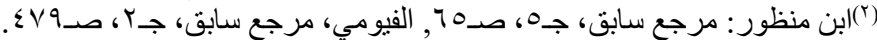

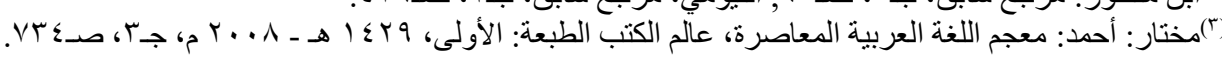


| 11 - حماية الملكية الفكرية في الأمن السيبراني

للإنسان في الحقول الأدبية والفنية، لذا ذاع لاى الفلاسفة الحديث عن العقل ودوره في

حياة صاحبه، إذ به يعز المرء أو يذل.(')

وقد تتوعت آراء الباحثين في تعريف الملكية الفكرية فجاء في تعريفها لدى علماء

الفقه الإسلامي المعاصرين بأنها حقوق معنوية، فالحق المعنوي هو سلطة لثخص على شيء غير مادي، هو ثمرة فكره أو خياله، أو نشاط؛ كحق المؤلف في مؤلفاته، وحق الفنان في مبتكراته الفنية، وحق الدخترع في مخترعاته الصناعية، وحق التاجر في الاسم

(†) التجاري والعلامة التجارية وثقة العلماء)

وعرفها آخر بحق الابتكار؛ فقال: هو اختصاص شرعي حاجز، يمنح صاحبه

سلطة مباشرة على انتاجه المبتكر أياً كان نوعه، ويككنه من الاحتفاظ بنسبة هذا الناتج

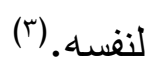

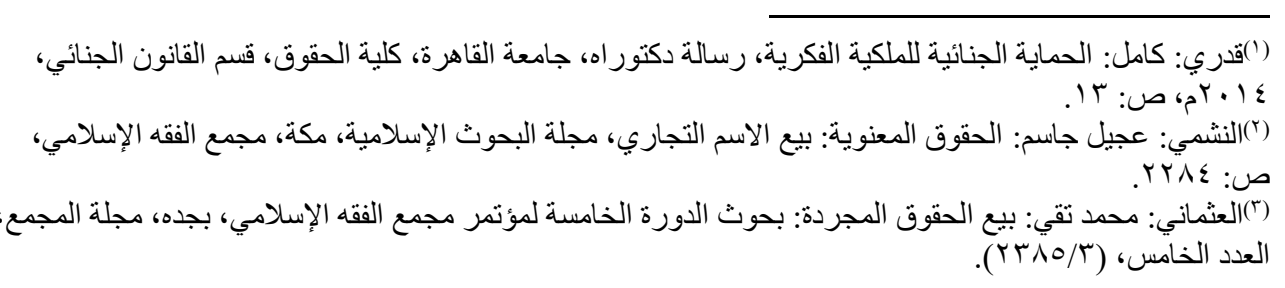


r.r. · · مجلة روح القوانين - العدد الثانى والتسعون - إصدار أكتوبر

وأما تعريفها لدى شراح القانون فعرفها البعض بأنها: "الأفكار والتعبيرات الخلاقة

للعقل البشري التي لها قيمة تجارية وتحظى بالحماية القانونية كحق من حقوق

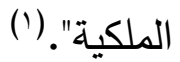

وأشارت المنظمة العالمية للمكية الفكرية لمعنى الملكية الفكرية فذكرت أنها

إبداعات العقل من اختراعات ومصنفات أدبية وفنية وتصاميم وشعارات وأسماء وصور مستخدمة في التجارة، وأبانت أن الملكية الفكرية محمية قانوناً بحقوق منها مثلاً البراءات وحق المؤلف والعلامات التجارية التي تمكّن الأشخاص من كسب الاعتراف أو فائدة مالية من ابتكارهم أو اختراعهم، ويرمي نظام الملكية الفكرية، من خلال إرساء توازن سليم بين مصالح المبتكرين ومصالح الجمهور العام، إلى إتاحة بيئة تساعد على ازدهار (ץ). الإبداع والابتكار

ومما سبق بيانه في تعريفات الملكية الفكرية فنجد أنها تدور حول الملكية الأدبية

والفنية والصناعية والتجارية ومهما تعدد هذه المسميات وهذا التنوع يعود إلى الجهة التي

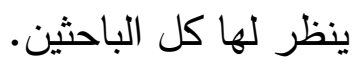


11

المطلب الثاني

مفهوم الأمن السييراني وعناصرهلغة واصطلاحاً

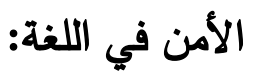

يدور الأمن في اللغة على سكون القلب وهدوء النفس وعدم الخوف، جاء في

مقاييس اللغة: الهمزة والميم والنون أصلان متقاربان: أحدها الأمانة التي هي ضد

الخيانة، ومعناها سكون القلب والآخر التصديق.(') وكنلك يدور حول الثقة والطمأنينة،

جاء في أساس البلاغة فلان أُمنَّة أي يأمن كل أحد ويثق به، ويأمنه الناس ولا يخافون

غائلته (r)

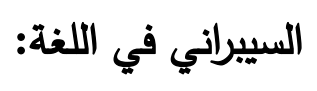

مصطلح السيبراني يعتبر واحد من أكثر المصطلحات تردداً في معجم الأمن

الدولي، وتشير الأبحاث على أن لفظة (CYBER) يونانية الأصل ومشتقة من كلمة

(kybernetes)

وتجدر الإثارة إلى أن العديد من المؤرخين يرجعون أصلها إلى عالم الرياضيات

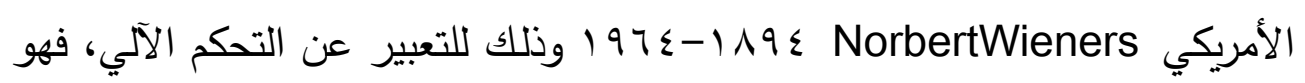

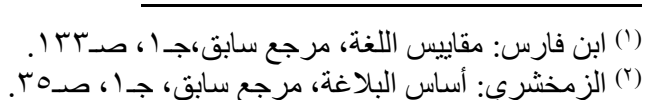

(s ro 
F. r · مجلة روح القوانين - العدد الثانى والتسعون - إصدار أكتوبر الأب الروحي المؤسـس للسـبرنيتيقية من خلال مؤلفه الثـــير : Cybernetics or control and communication in" the Animal and the machine في كتابه إلى أن السبرنتيقية هي التحكم والتواصل عند الحيوان والآلة والإنسـان والآلة ليستبدل مصطلح الآلة بعد الحرب العالمية الثانية بالحاسوب.(')

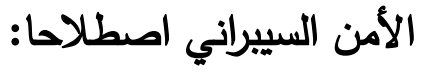

وردت العديد من التعاريف لمفهوم الأمن السيبراني، ومنها مجموعة من الإجراءات المتخذة في مجال الدفاع ضد الهجمات السييرانية ونتائجها التي تشمل تنفيذ التدابير

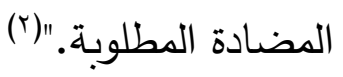
جاء في تعريف الهيئة الوطنية للأمن السيبراني: " حماية الشبكات وأنظمة تقنية المعلومات وأنظمة التقنيات التثغيلية، ومكوناتها من عتاد وبرمجيات، وما تقدمه من خدمات، وما تحويه من بيانات، من أي اختراق، أو تعطيل، أو تعديل، أو دخول، أو استخدام، أو استغلال غير مشروع".(")

(1) مقال بعنوان: الأمن السييراني، منشور على الموقع https:/political-encyclopedia.org/dictionary تاريخ

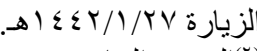

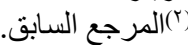

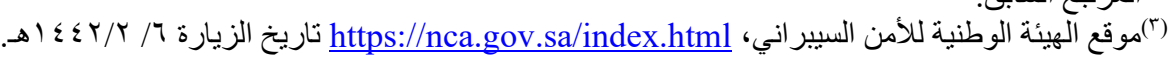


11 - 11

ويشير عدد من الباحثين إلى أن الأمن السييراني عبارة عن " جميع العمليات التي

تستهدف حماية أصول تكنلوجيا المعلومات المئكونة للفضاء السيبراني".(')

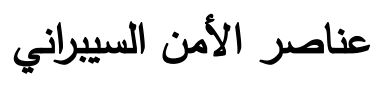

الهفف الذي الأساسي الذي يقوم عليه الأمن السيبراني هو حماية الهوية الخاصة

بالأثخاص أو النظمات سواءً كانت حكومية أم خاصة؛ كنلك حماية أجهزة الحواسب

والخوادم البيانات والمعلومات الثخصية للأفراد أو الكنظمات، وحتى يتحقق الهدف والغاية لابد من توفر مجموعة من العناصر ليكتمل الدور في ذلك، ومن أهم تلك

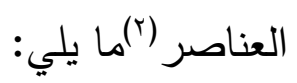

(أولاً: التقنية : تشكل التكنولوجيا والتقنية دورًا في غاية الأهمية (technology)

في حياة الأفراد والمنظمات، حيث توفر الحماية الفائقة لهم أمام الهجمات السيبرانية، وتثتمل حماية الأجهزة بمختلف أثكالها الذكية والحاسوبية والثبكات بالاعتماد على جدران الحماية واستخدام البرامج الضارة ومكافحة الفيروسات وغيرها. ثانياً: الأشخاص(People) :يستوجب الأمر لزومًا على الأشخاص من مستخدمي البيانات والأنظمة في منشأة ما استخدام مبادئ حماية البيانات الرئيسية

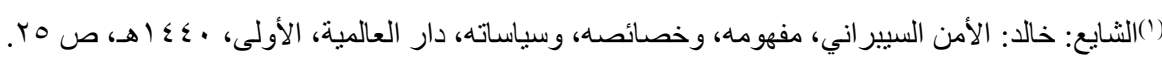

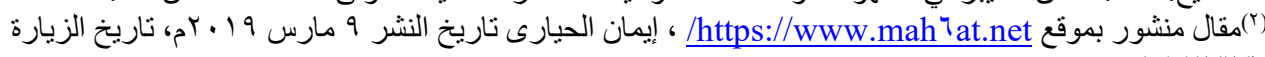




$$
\begin{aligned}
& \text { r.r. · مجلة روح القوانين - العدد الثانى والتسعون - إصدار أكتوبر } \\
& \text { كتحديد كلمة مرور قوية، وتفادي فتح الروابط الخارجية والمرفقات عبر البريد } \\
& \text { الإكتروني، إلى جانبٍ القيام بعمل نسخ احتياطية للبيانات. }
\end{aligned}
$$

ثالثاً: الأنشطة والعمليات(Process) :يتم توظيف الأشخاص والتقنيات للقيام

بالعديد من العمليات والأنشطة وتسييرها بما يتماشى مع تطبيق أسس الأمن السيبراني والتصدي لهجماته بكل كفاءة.

ومما سبق بيانه يمكن إعطاء تعريفاً للأمن السيبراني في مجال حماية المليكة

الفكرية بأنه: النشاط الذي يحمي أنواع المليكة الفكرية المرتبطة بالتقنيات الحديثة للاتصالات والمعلومات، مع ضمان الحد من الخسائر والأضرار الواقعة أو محتملة الوقوع. 
11 - حماية الملكية الفكرية في الأمن السيبراني

المطلب الثالث

\section{علاقة الأمن السييراني بحقوق الملكية الفكرية}

لا شك أن البيئة الرقمية ساعدت في انتشار المعرفة بشتى أنواعها، وأضحى ذلك

إلى سهولة النقل والتحميل والاختزال لكل أبواب المعرفة، وهذا الأمر أحدث قضية سلبية أمام حماية حقوق الملكية الفكرية بشتى أنوعها، حيث أصبح الأمن السيبراني كقضية ناشئة في حقل حماية الملكية الفكرية من خلال حداثته أمام مجالات الملكية الفكرية. وآية ذلك أنه تتوفر في البيئة المعلوماتية إمكانية إقتباس وتعديل ونشر البرمجيات مما يجعلها عرضة للسطو عليها وإعادة إنتاجها، إضافة إلى امكانية الاطلاع على معلومات الآخرين وسرقتها، تحريفها أو تخريبها والتشويش عليها، حيث يعيش العالم أجمع عصر المعلومات، حيث أضحت الاتصالات والمعلومات من أعلى القيم المستحدثة، باعتبارها عماد جميع الأنشطة السياسية والاقتصادية والاجتماعية في حياة الأفراد والدول، إذ يعتمد الأفراد وكذا القطاع العام والخاص في الأنشطة اليومية على تكنولوجيا المعلومات والاتصالات ويظهر ذلك في النقل البري والجوي والبحري والاتصالات السلكية 
مجلة روح القوانين - العدد الثانى والتسعون - إصدار أكتوبر ·r.r. ماللاسلكية والمستثفيات والخدمات العامة والتجارة الإكترونية والمؤسسات المالية

والعسكرية وغيرها (') (2) (2)

ومعلوم أن الجريمة تستهدف ما لله قيمة في الحياة، لذا ظهرت الجريمة الإلكترونية

وهي تتثــابه مع الجريمة التقليدية في ضـــرورة وجود مجرم وضــــية وأداة ومكان

للجريمة. ويختلفان في أن الجريمة الإكترونيـة تتطلب وجود بيئة رقميـة واتصــــال بالانترنت، مما يعني أن جمع الأدلة من مسرح الجريمة يقتضي البحث عن تلك الأدلة من خلال مسرحين:

المسرح التقليدي، وهو الواقع خارج البيئة المعلوماتية، كالبصـمات التي يتركها الجاني ومتعلقاته ونحوها.

المســرح الســييراني، وهو الواقع داخل البيئة الحاســـوبية، ويشــــل على البيانات والمعلومات في الذاكرة والأقراص والثبكة، والتعامل مع هذا النوع من الأدلة لا يتم إلا من خلال خبير متخصص في الأدلة الرقمية(؟).

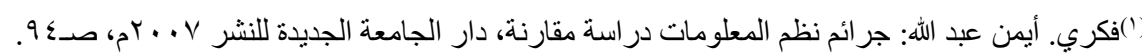

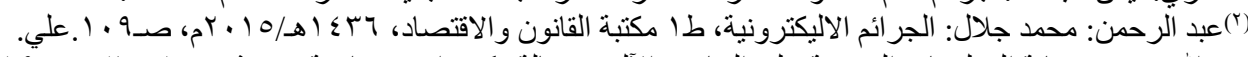

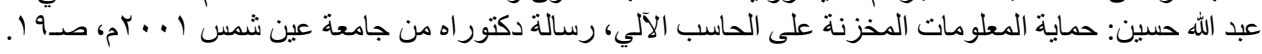
$\{\leqslant \leqslant$ 
| 11 - حماية الملكية الفكرية في الأمن السيبراني

ومن ناحية أخرى فإن أداة الجريمة الإكترونية ذات تقنية عالية، كما أن مكان

الجريمة الإلكترونية لا يتطلب انتقال الجاني إليه وإنما تتم الجريمة عن بعد باسـتخدام

خطوط وشبكات الاتصـال بين الجاني ومكان تنفيذ الجريمة، فضـلا عن البعد الدولي لهذا النوع من الجرائم، ومن ثم فإن الســـاحة الإجرامية في الجرائم المعلوماتية تثير تحديات واســـة حيث يمكن التخطيط للجريمة في دولة ويكون المنفذون في دولة أخرى، وتقع آثار الجريـة في مكان ثالث، مهـا يثير مثــــاكل نظاميـة تتعلق بالاختصـاص والإثبات ونحو ذلك؛ بالإضـافة إلى أن الجريمة المعلوماتية يصـب التحقق منها، ويصـعب القبض على مرتكبيها، إضـافة إلى صـعوبة الدحاكمة لعدم

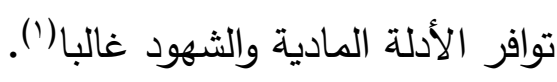

وقد كانت المملكة من أولى الدول التي سارعت إلى الوقوف أمام هذا النوع من الجرائم المستحدثة بسن نظام مكافحة جرائم المعلوماتية، وهو يتمثل في مجموعة من القواعد النظامية التي تبين ماهية الأفعال التي تعد جرائم في مجال المعلوماتية وتحدد العقوبات التي تطبق على متترفها؛ وهي قواعد خاصة، تترر أعمالا محظورة ووقائع صادرة عن إرادة جنائية - مضرة بالصالح العام.

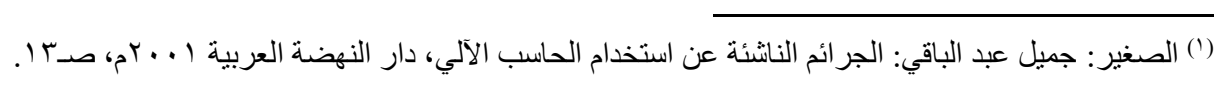
$\{$ (纟) $\}$ 
r.r. · مجلة روح القوانين - العدد الثانى والتسعون - إصدار أكتوبر وقد تتاول نظام مكافحة جرائم المعلوماتية - محل الثــرح - جميع أنواع السـلوك الإجرامي الذي يتصــــور وقوعـه في البيئة الرقيـة، وهي تدور حول الدخول غير المشـروع والمســاس بالحياة الخاصــة والتثـــير بالآخرين، والاسـتيلاء على الأموال المنقولة والوصــــول دون مســــوغ نظامي الى المعلومات البنكية والائتمانية، وإتلاف البرامج والبيانات وإعاقة الوصـــــل الى الخدمة، وكذا الجرائم الماســــة بالنظام العام والآداب العامة وأمن المجتمع وغير ذلك.

وتتميز الجريمة الإكترونية بجملة من الخصـــائص أهمها خفاء الجريمة وعدم السهولة في ملاحظتها، وكذا سهولة تنفيذها وخلوها من العنف المادي. وكونها جريمة عابرة للحدود. إضافة إلى صعوبة الوصول الى الجرائم المعلوماتية. حيث إن هذا النوع من الجرائم يتسم بسـرعة التنفيذ وسـهولة الاخفاء وسـرعة محو الآثار ، وبالتالي تواجه أجهزة البحث والتحقيق صعوبات كثيرة في كثفها، مما يقتضي اعداد برامج تدريب وتأهيل لتلك الكوادر لتحقيق المهام المطلوبة منها بدقة وكفاءة، 
11 - 11

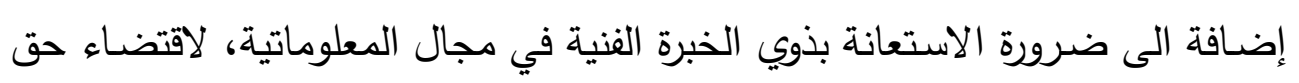

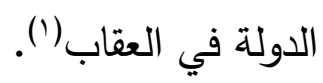

وقد تعود صعوبة الكثف عن هذه الجرائم الى عدم رغبة المجني عليه في التبليخ

عن الجريمة خشية التثـهير سـيما إن وقعت الجريمة على المؤسســات المالية التي

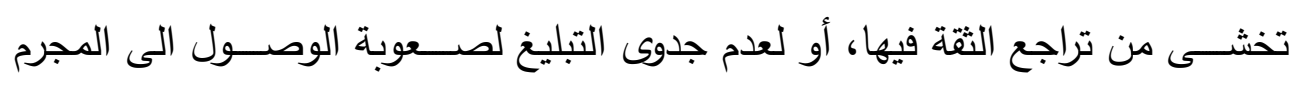
المعلوماتي، وسـرعة محو الأدلة، أو توافر الوســائل التقنية التي تعرقل الوصـول إلى لـ

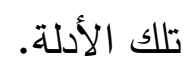

وتتعدد صـور هذه الجرائم فقد تتم من خلال الرســائل النصـية وذلك عن طريق

كتابة رســائل الكترونية وبثها للغير sms أو بلوتوث أو بالبريد الاكتروني أو عن طريق غرف الدردشة، بأن ينسب شخص الى غيره أفعالا مشينة لابتزاه مثلا، وقد تقع تامة وقد تقف عند حد الثروع.

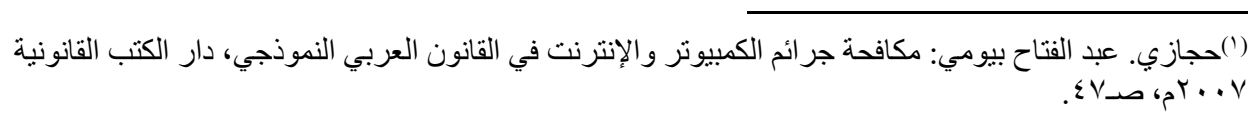
$(\leqslant \leqslant r)$ 
r. r · مجلة روح القوانين - العدد الثانى والتسعون - إصدار أكتوبر ومنها استخدام ذاكرة التليفون ونحوه لتخزين المواد غير المشروعة، وقد ترتكب من خلال الكاميرا بتصوير المقاطع الفيديوية أو الصور العادية للضحية في أوضاع غير لائقة للابتزاز أو الترويج للاباحيات.

وقد تتم تلك الجرائم من خلال نشر البرامج العدائية كالفيروسات وبرامج التجسس للاعتداء على خصـوصـيات الآخرين وأسـرارهم العائلية أو التجارية، أو إثـعال الفتن الطائفية أو لبث الثائعات، وسرقة الملفات وانتحال الشخصيات.

وتتعدد الأغراض الدافعة لارتكاب الجريمة المعلوماتية، فقد تكون أهدافا مادية كتحقيق الكســـب المالي، أو معنوية كالتعلم واكتســـاب المهارات الذهنية، أو مجرد الانتقام ونحو ذلك.

ومما ينم عن حجم وخطورة الجرائم المعلوماتية ما أفصحت عنه أحد الدراسات من وجود أكثر من بr مليون عملية هجوم الكترونية صـدرت عن جr ا دولة حول العالم على أنظمة الحاسب الآلي كما واجه مسـتخدو أجهزة الحاسـب الآلي في 10 ب دولة

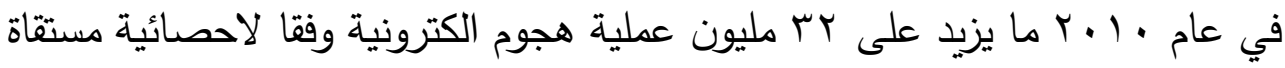
من دراســــة لأمن الانترنت خلال الملتقى العلمي لمكافحة الجرائم المعلوماتية لمنتـى 
11

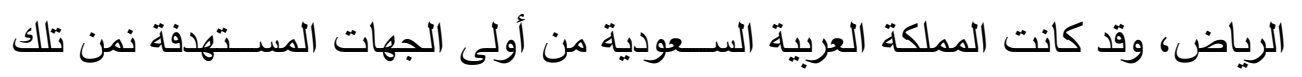

العمليات غير المشـروعة حيث كان معدل الانتهاكات بثــأنها بr,r, ٪ من جملة

$$
\text { الاعتداءات('). }
$$

ضرورة اللجوء إلى التظلل بمظلة حماية الملكية النكرية للبرامج المعلوماتية.

إن تطور تتنيات البرمجيات وتنامي شبكة الانترنت وإدخال المعلوماتية إلى جميع

النشاطات البرية قد أدى بدروه إلى تعاظم إنتاج برامج وقواعد البيانات والأعمال الرقمية، بل تطور الأمر حتى ظهر ما يعرف بالاقتصاد الرقمي. فتتامت وصناعة البرمجيات وتم بحث سبل حماية هذا الإنتاج الرقمي، الذي يقوم على الابتكار والجة. ومن جهة أخرى تزايدت أعمال التعدي على هذا الإنتاج من خلال النسخ غير الدشروع والتحميل من الإنترنت، ونحوها من أعمال التعدي على حقوق أصحاب البرامج وقواعد البيانات والأعمال الرقمية، مما يشكل عائقا أمام ازدهار هذا القطاع وتشجيع

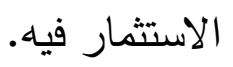

والحل هو فرض حماية قانونية فعالة، تردع المنتهكين، وتحفظ حقوق الهنتجين والمبدعين، وتحفزهم للتطوير ، ويلزم لفرض تلك الحماية على تلك الأعمال الرقمية أن 
r. r · مجلة روح القوانين - العدد الثانى والتسعون - إصدار أكتوبر تتخذ البرامج المعلوماتية صورة في الواقع الملموس، حتى وإن كانت تظهر وتختفي على الشاشة ولا يمكن رؤيتها إلا بالوسيط الإلكتروني، ولا تقف عند حد كونها فكرة ذهنية لم تخرج للواقع. فهي محمية وإن كانت مدمجة ضمن التجهيزات لتشغيله('). كما تشمل الحماية أعمال التصميم التحضيرية شريطة توافز عنصر الجدة والابتكار، والتعبير عنه في شكل ما. وحقوق مؤلف العمل الرقمي تتمثل في حق نِسبة العمل إلى مبتكره، وحق المؤلف في نشر العمل أو إشهار العمل، وحق المؤلف في منع أي تحوير أو تعديل أو تغيير في العمل ضمن شروط معينة، وهو حق محدود جداً في حالة البرامج المعوماتية، أما حق المؤلف في سحب العمل فلا يمكن سريانه في حالة البرامج المعلوماتية. وبشأن الحقوق المادية التي تتعلق باستثمار أو استغلال البرنامج المعلوماتي فلمؤلف العمل الرقمي وحده حق نسخ وإعادة إنتاج العمل بشكل دائم أو مؤقت للبرنامج المعلوماتي جزئياً أو كلياً بأية وسيلة كانت وبأي شكل كان، كما له الحق في ترجمة البرنامج وتكييفه وإعادة ترتيبه وكل تعديل أو تحويل أو إعادة إنتاج، مع حفظ حقوقه 
| 11 - حماية الملكية الفكرية في الأمن السيبراني

كاملة في النشر والتوزيع والنقل والبيع والتأجير للجمهور للنسخة الأصلية أو المأخوذة

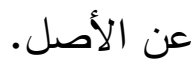

كما يكون للثخص الذي له الحق في استخدامه صنح نسخة لحفظ هذا البرنامج

طالما أنها ضرورية للاستخام، وله مراقبة طريقة عمل البرنامج أو دراستها أو فحصها، من أجل دون اشتراط موافقة صاحب حق المؤلف، كما أن له حل شيفرة البرنامج أو ترجمة شكل هذه البرمجيات من أجل الحصول على المعلومات اللازمة لتثغيل البرنامج

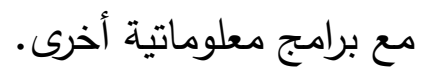

وبشأن حماية قواعد البيانات بموجب قانون حقوق المؤلف، فإننا نشير إلى أن قواعد

البيانات هي مجموعة أعمال أو بيانات أو عناصر أخرى مستقلة منظمة بطريقة منهجية وممكن للوصول إليها بوسائل إلكترونية أو بأية وسيلة، وهي قد تكون أعمال أدبية أو فنيةً أو موسيقية أو نصية أو صوتية أو مجموعة صور أو أرقام أو وقائع أو بيانات أو غيرها. فقواعد البيانات هي الوعاء الذي يسحح بحفظ كميات هائلة من المعلومات وإدارتها للجهة التي تضيفها، ومن ثم يكون لهذه الجهة حق الإضافة والتعديل

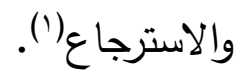

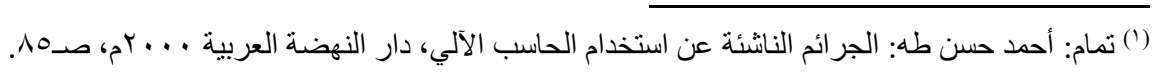
$\{\leq \leqslant \vee\}$ 
r.Y. مجلة روح القوانين - العدد الثانى والتسعون - إصدار أكتوبر ولهذا تتعين التفرقة بين قاعدة البيانات، وهي الظرف الذي يحتوي على البيانات، والبيانات نفسها ومنتج أو صانع قاعدة البيانات هو الثخص الذي يقوم بإنشائها، فله منع أي شخص آخر من استخراج وإعادة استعمال محتوى قاعدة البيانات، سواء كان ذلك يهدف ذلك لصنع منتج آخر منافس. ومن أمثلتها أسماء المواقع فهارسها وصفحاتها ومحركات البحث والرسوم والصور وألعاب الفيديو والوسائط المتعددة. $(\varepsilon \varepsilon \wedge)$ 
11

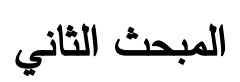

\section{مهددات الملكية الفكرية في الأمن السيبراني}

تحظى الملكية الفكرية اهتماماً بالغاً على كل الأصعدة المحلية والدولية، ويأتي هذا الاهتمام بالتصدي لكل أنواع الاعتداءات والمهددات بشكل عام وفي فضاء الأمن السيبراني بشكل خاص، ويأتي هذا المبحث للحديث عن جملة من التهديدات لمجالات الملكية الفكرية في الأمن السيبراني وفق المطالب التالية.

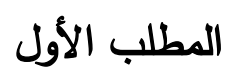

\section{الاعتداءات الخاصة بأمن المعلومات وقيمتها}

برزت الثورة المعلوماتية مع بداية القرن العشرين نتيجة للتقدم العلمي والتكنولوجي

سيما تقنية الحاسب الآلي والثبكات الإكترونية، وقديما قيل: يحدث للناس من الأقضية بقدر ما يحدثوا من الفجور ، فظهرت جرائم ليست مجرد جرائم تقليدية في ثوب جديد، أو بوسائل مختلفة فحسب بل ظهرت جرائم تمثلت في عمليات الاقتحام والهجوم على الحاسبات والنظم المعلوماتية تخربها وتدرها وتسرق محتوياتها وتنشر الفيروسات، بالإضافة إلى ظهور الجرائم التقليدية في ثوب معلوماتي كاتصال أفراد العصابات المنظمة لتتبير جرائمهم وكذا جرائم التهريب والمخدرات والاتجار في الرقيق والبغاء 


$$
\text { r.r. · مجلة روح القوانين - العدد الثانى والتسعون - إصدار أكتوبر }
$$

والاتجار في الاسلحة ونحوها. ومن ثم ظهرت العديد من أنواع الاعتداءات بأمن المعلومات وقيمتها التي أثّرت على حقوق مجالات الملكية الفكرية، وتختلف وفقاً لطبيعة الحقوق التي تُهاجمها، وفي هذا المطلب سأتحدث عن تلك الاعتداءات الخاصة بأمن المعلومات وقيمة المعلومات المعالجة آلياً، وذلك في فرعين.

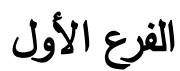

\section{الاعتداءات الخاصة بأمن المعومات المعالجة آلياً}

ظل هذا المجال من الأمن حتى اواخر السبعينات معروفا باسم أمن الاتصالات والذي حددته توصيات أمن أنظمة المعلومات والاتصالات لوكالة الأمن القومي في الولايات المتحدة بأنه: " المعايير والاجراءات المتخذة لـنع وصول المعلومات إلى أيدي أشخاص غير مخولين عبر الاتصالات ولضمان أصالة وصحة هذه

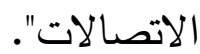

وفي الثمانينات مع النمو للحاسبات الثخصية بدأت حقبة جديدة من الأمن سميت أمن الحواسيب، والتي حدت بكونها" المعايير والاجراءات التي تضمن سرية 
11

كمال توافر مكونات انظمة المعلومات بما فيها التجهيزات والبرامجيات والمعلومات

$$
\text { التي تم معالجتها وتخزينها ونقلها"(') }
$$

وفي التسعينات من القرن الماضي تم دمج مفهومي الأمن السابقين ليعرف هذا

النظام بأمن أنظمة المعلومات، الذي يعرف بأنه: "حماية أنظمة المعلومات ضد أي وصول غير مرخص أو تعديل المعلومات أثناء حفظها، أو معالجتها أو نقلها، وضد إيقاف عمل الخدمة لصالح المستخدمين المخولين أو تقديم الخدمة لأشخاص غير مخولين بما في ذلك جميع الإجراءات الضرورية لكثف توثيق ومواجهة هذه

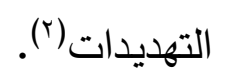

وتكمن الاعتداءات الخاصة بأمن المعلومات على المعطيات السرية المحمية

$$
\text { قانوناً وغير المصرح بتداولها، والبيانات التي تمس الخصوصية. }
$$

ويقصد بالخصوصية أو السرية تلك الخصوصية للمعلومات المتعلقة بالعملاء أو بالمنظمة، فهذه المعلومات يتعين أن تكون بعيدة عن وصول غير المصرح لهم بالاطلاع عليها. وتحمى هذه الخصوصيات عن طريق نظام التشفير، الذي يوفر مستوى عالٍ

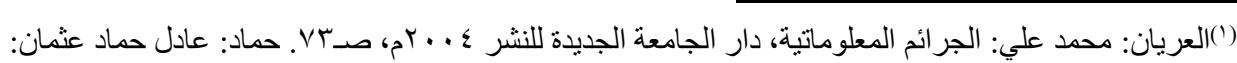

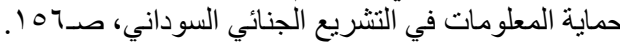

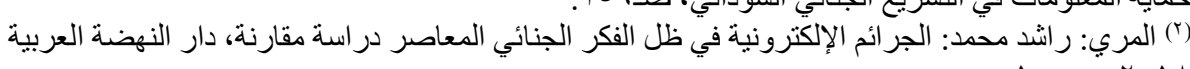


F. r · مجلة روح القوانين - العدد الثانى والتسعون - إصدار أكتوبر من الأمن للمعلومات مع المحافظة على المرونة في تداول تلك البيانات، كما يحمي السلامة للمعلومات والأنظمة: بحيث يمكن التأكد من عدم تعرضها لأي نوع من التغيير الغير مصرح به، وبعبارة أخرى فإن البيانات لا يمكن أن يحدث لها استحداث أو تغيير أو حذف من غير تصريح، وكذلك تعني أن البيانات المخزنة في أحد أجزاء جداول قواعد البيانات متوافقة مع ما يقابلها من البيانات المخزنة في جزء آخر من قواعد البيانات، ويراعى أن ضمان عناصر أمن المعلومات كلها او بعضها يعتمد على المعلومات محل الحماية واستخداماتها وعلى الخدمات المتصلة بها، فليس كل المعلومات تتطلب السرية وضمان عدم الافثاء، وليس كل المعلومات في منشأة واحدة بذات الاهمية من حيث الوصول لها او ضمان عدم العبث بها('). صور السلوك الإجرامي في الاعتداءات الخاصة بأمن المعلومات المعالجة آلياً: تتمثل أنماط السلوك الإجرامي في هذا الصدد فيما يلي: الصـورة الأولى: التصــت على ما هو مرسـل عن طريق الشـبكة المعلوماتية أو أحد أجهزة الحاسب الآلي - دون مسوغ نظامي صحيح - أو التقاطه أو اعتراضه. 
11

أ- - التتصت على ما هو مرسل عن طريق الشبكة المعلوماتية أو أحد أجهزة الحاسب الآلي دون مسوغ نظامي صحيح.

ويشـــل ذلك كل ما يرسـل عن طريق الثـبكة المعلوماتية أو أجهزة الحاسـب

الآلي، سواء تعلق بالحياة الخاصة أو المسائل المالية أو غيرهما، كالمراسلات الكتابية والصوتية والمكالمات وغيرهما.

والتتصــت من نصــت، والإنصـات: السـكوت والاسـتماع، وأنصــت له اسـتمع لحيثه(')، فهو جريمة سمعية بمعنى أنه يستهدف الأصسوات المسموعة المرسلة عبر الشبكة المعلوماتية، أو الموجودة على أحد أجهزة الحاسب الآلي، سواء أكانت أصوات أشخاص أو غيرها.

والتتصـــت المعلوماتي من جرائم انتهاك الخصــوصــية والاعتداء على حرمة

الأثــخاص وخصـوصـياتهم، والاطلاع غير المصـرح به على لمعلومات المخزنة أو المتداولة آليا، ويلزم لقيامها وجود الجاني بيئة المعالجة الآلية للمعلومات(؟).

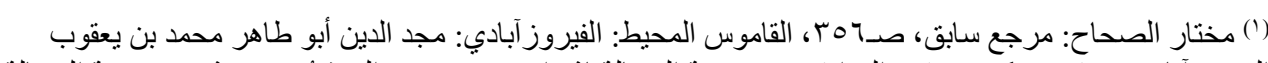

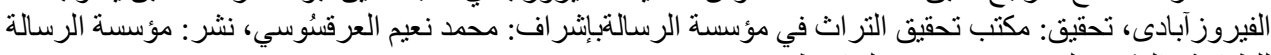

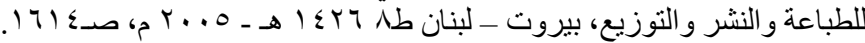

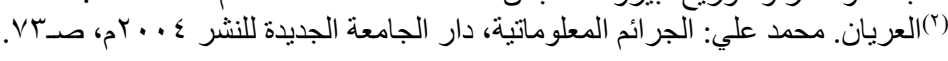
(sor) 


$$
\text { r.r. · مجلة روح القوانين - العدد الثانى والتسعون - إصدار أكتوبر }
$$

ويلزم لقيام تلك الجريمة أن يكون الجاني قادرا على السمع ولو لم يكن يفهم اللغة

المسموعة، فإن لم يكن قادرا على التسمع لصمم أو لأن المادة المرسلة غير مسموعة فنتنفي هذه الجريمة(') على نحو لا يمنع من قيام جريمة الاطلاع أو الاعتراض حسب

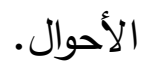

وقد يقع التتصــت عن طريق الهاكرز أو الاختراق، وهو الوصــول بطريقة غير مشــروعة الى هدف معين عن طريق ثغرات في المنافذ، كالثغرات في نظام الحماية الخاص بالهدف، للتجسس والاستماع أو التسجيل أو تحويل سير البيانات والاستيلاء عليها (r)

وقد يتم التتصـت عن طريق المحاكاة أو انتحال الثخصـية للدخول الى النظام، والوصـول الى عنوان المرسـل أو المرسـل إليه والتواصـل معه على أنه عنوان مقبول وساري المفعول وقادم من جهاز معين، بينما هو في الحقيقة غير ذلك. وتســـخدم في عمليات التتصـــت المعلوماتي مكبرات الصـــوت والميكروفات الصغيرة، كما أن هناك مراكز للتتصت، حيث يقوم قراصنة الحاسب الآلي باستخدام 
| 11 - حماية الملكية الفكرية في الأمن السيبراني

البرامج التي تتيح لهم التجسـس على المعلومات الخاصـة بالثـركات والمؤسـســات التجارية العاملة على شبكة الانترنت، للحصول على ما يريدونه من معلومات.

ولا يمنع من قيام تلك الجريمة أن يكون الجاني له الحق في تلقي واســـتقبال البيانات، إذا قام باستعمالها في غير الأغراض المسموح بها (1).

ولا تتحق جريمة التصت إذا أعلن ذو الثأن رضاه بهذا التتصت أو أذن فيه، أو كانت تلك المواد منشورة بصورة علنية تمكن الجميع من الاطلاع عليها وسماعها. ب-التقاط ما هو مرسل عن طريق الشبكة المعلوماتية أو أحد أجهزة الحاسب الآلي - دون مسوغ نظامي صحيح.

فالواقع أن المعلومات تظهر على شــاثــة الحاسـب، كما أنها مخزنة في ذاكرة

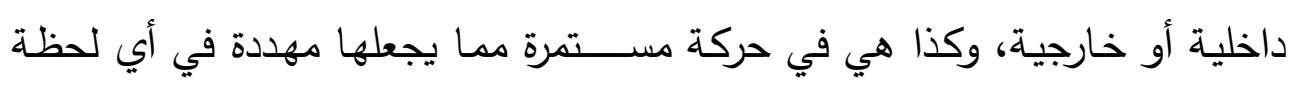

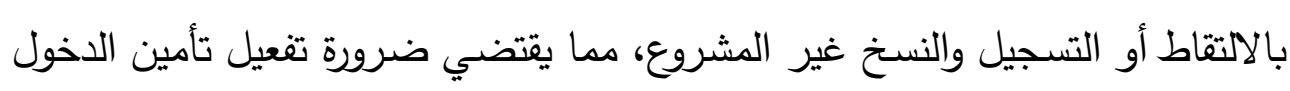
الى المراكز المعلوماتية للحفاظ على البث المعلوماتي.

وقد عرفت المادة الأولى من نظام مكافحة جرائم المعلوماتية السعودي، الالتقاط بأنه: "مشاهدة البيانات، أو الحصول عليها دون مسوغ نظامي صحيح". 
r. r · مجلة روح القوانين - العدد الثانى والتسعون - إصدار أكتوبر

ويســتوي أن يتم الالتقاط والاعتراض عن طريق الدخول إلى الثـــــكة أو دون الدخول، كما في حالة التقاط الإثــارات التي يحدثها جهاز الكتروني دون الحاجة الى لـ

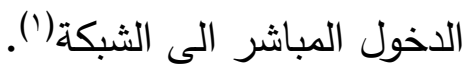

ويســتوي أن ينصـــب الالتقاط على المعلومات أو التوقيع الســري أو الأرقام

التثفيرية ونحو ذلك. وهناك طرائق عديدة يمكن من خلالها التقاط المعلومات ومنها: أ- الالتقاط الذهني للمعلومات، وذلك عن طريق المشاهدة أو الاستماع لما يصدر

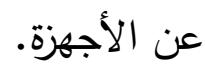
ب- التقاط المعلومات الموجودة بين الحاســـب والنهاية الطرفية، وذلك من خلال توصـيل تحويلة الى الطرف القائم بالتجسـس ترسـل إثــارات الكترونية مكبرة، تمثل

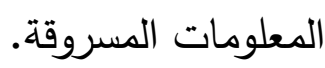
ج- التقاط الذبذبات الصادرة عن هوائي مستقبل لإرسال القمر الصناعي. د- التوصيل المباشر على خط تليفوني عن طريق وضع مركز تتصت يسجل كل الاتصالات، أو بواسطة ميكروفونات صغيرة. 
| 11 - حماية الملكية الفكرية في الأمن السيبراني

هـ - التقاط الإثعاعات الصادرة عن الجهاز الدعلوماتي وترجمتها عن طريق أجهزة

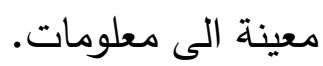

\section{ز - التدل عن طريق نقاط الاتصال (1).}

وهناك وسائل تقنية لحماية سرية المعلومات والاتصالات، ومنها تشفير المعلومات المرسلة حتى لا يتمكن من الاطلاع عليها سوى المصرح له بذلك.

والالتقاط أثــبه ما يكون بالســرقة حيث إن الجاني يقوم بالذخول إلى محل لا يسمح له بالذخول إليه ثم يسرق أو يستولي على ما به من معلومات قابلة للتملك ولها قيمتها الاقتصادية من خلال نسخها على مستندات أو شرائط أو حتى مجرد الاحتفاظ بها في الذاكرة، وسواء حصل على تلك المعلومات والبيانات خلسة أو عنوة. ت-اعتراض ما هو مرسل عن طريق الثبكة المعلوماتية أو أحد أجهزة الحاسب الآلي -

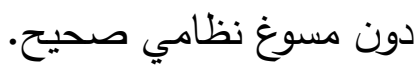


r. r. • مجلة روح القوانين - العدد الثانى والتسعون - إصدار أكتوبر والاعتراض يقتضـي وجود اتصـال بين طرفين أو أكثر ، ثم يحصـل تغريع سـري خفي أو تفريعة تقدمها شركات التليفونات، تقوم باعتراض الإشارة فحسب دون تفكيكها وتحليلها، لأن التفكيك والتحليل يدخل في نطاق الالتقاط ('). وغالبا ما تتم هذه الأفعال من خلال الهاكرز أو الكتسلل، وهم أشخاص بارعون في استخدام الوسائل الحديثة لاختراق حسابات الآخرين، بهدف التجسس أو التخريب والتدمير أو السرقة أو مجرد الاطلاع على المعلومات الشخصية والمالية، أو بدافع الفضول والتحدي لإجراءات أمن المعلومات، والأنظمة الأمنية للحاسب، والبحث عن الثغرات الأمنية في النظام محل الاعتداء(「). الصورة الثانية: الدخول غير المشروع أو غير المصرح به (الاختراق). تولي الأنظمة اتجاه الجرائم المعلوماتية المواقع الإكترونية والصفحات والمعلومات الإلكترونية أهمية في نصوصها، لذا فإنها تجرم مجرد الدخول غير المشروع الى تلك الكيانات كما تجرم الاعتداء على محتوياتها بالتدمير أو التزوير، أو التدخل بأي شكل غير مشروع كالنصب والاحتيال الاككتروني؛ ومن ناحية أخرى تهتم المواقع والأنظمة 
| 11 - حماية الملكية الفكرية في الأمن السيبراني

الإكترونية والمؤسسات المعلوماتية بالوقوف ضد تلك التعديات من خلال الحوائط

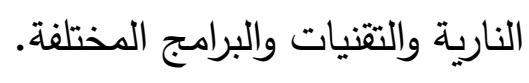

وجريمة الدخول غير المشروع جريمة بسيطة يكفي لقيامها ارتكاب فعل واحد،

والجريمة البسيطة تختلف عن جرائم الاعتياد التي لا يكفي لقيامها ارتكاب فعل واحد

بل تتكون من تكرار الفعل والاعتياد عليه، وحالتئذ يكون الركن المادي الدكون لجريمة

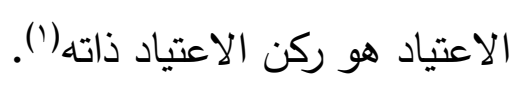

وتقوم جريمة الدخول غير المشروع سواء كان هذا الدخول وقتيا او مستمرا

ومتجدا، فلا يلزم لتيامها أن يكون الدخول متجددا ومتتابعا، وسياتتي الكلام عن جريمة

البقاء غير المشروع، وهذه الأخيرة قد تكون متتابعة الأفعال وذلك إذا تكونت من دخول

غير مشروع وتلاه بقاء غير مشروع، وقد تأتي في شكل أولي لا تتابع فيه كما في حالة الدخول الصصرح به مع استمرار البقاء غير الدشروع.

كما أن جريمة الدخول غير الصصرح به من الجرائم العدية التي يتخذ الركن المعنوي فيها صورة القصد الجنائي أي ارادة الفعل والنتيجة وتوافر كافة العناصر ' حجازي:عبا الفناح بيومي: جرائم الكبيوتر والانترنت، مرجع سابق، صدبr. $\{$ \{ 09$\}$ 
r. r. · مجلة روح القوانين - العدد الثانى والتسعون - إصدار أكتوبر النظامية المتطلبة لقيام الجريمة، وبناء على ذلك فلو كان الدخول غير المشروع قد تم بغير العدد وانما بطريق الخطأ المتمثل في الاهمال والرعونة وعدم الاحتياط وعدم الاحتراز فلا تقوم جريمة الاخول، وآية ذلك أن يخرج من النطاق غير المرخص له بذخوله فور علمه بعدم مشروعية الدخول، لكن بقاءه مع علمه يعد قرينة على القصد

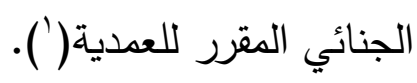
كما ينبغي الاشارة الى أن جريمة الدخول غير المصرح به تكون جريمة عادية وجريمة سياسية، وتتحقق هذه الأخيرة حال وقوع الاعتداء على النظام السياسي للدولة كثكل الدولة ونظامها السياسي والحقوق الأساسية للأفراد، ومن ثم فهي أخطر في آثارها من الجريمة العادية، مما يترتب عليه أن تكون عقوباتها أشد وأنكى. ويتمثل الركن المادي لجريمة الدخول غير يعني المظاهر الخارجية المكونة لماديات الجريمة، أي الثكل الذي تظهر فيه الجريمة الى العالم الخارجي المحيط بالجاني، والكيان الملموس الذي يظهر على الأجهز والمواقع ونحوها من الكيانات المعلوماتية، وهذا الركن هو الذي ييرر تدخل النظام بالتجريم، فلو انعدم وجوده فليس ' الرومي: محمد أمين: جرائم الكمبيوتر والانترنت، دار المطبوعات الجامعية ع .. بم، صـ Y. 
11 - 11

ثدة جريمة، إذ لا جريمة دون سلوك مادي، فالإثبات للجريمة يقع على الماديات، لأن الماديات هي التي يمكن اثباتها.

والركن المادي لأي جريمة يتكون من السلوك الاجرامي والنتيجة التي يسفر عنها هذا السلوك والسبيية بينهما، فمتى اكتملت هذه العناصر كانت الجريمة تامة ووجب توقيع العقاب على مرتكبها، أما إذا لم تتحقق النتيجة وكان عدم التحقق راجعا الى أباب لا دخل لإرادة الجاني فيها فحالتئذ يقف الفعل عند حد الشروع ويعاقب مقترف الفعل بناء على هذا الوصف وهو الثروع إن كان ثة عقاب على الثروع('). كما أن السلوك الإجرامي يقدم عليه الجاني بمفرده وقد يستعين بمساهمين في ارتكاب السلوك الاجرامي بأي من صور الدساهمة، وقد تكون الدساهمة بأدوار رئيسة وحالثئذ يكون كل فاعل مساهم أصلي في الجريمة، وقد تكون بأدوار ثانوية وحالتئ يكون كل مساهم تبعي شريك مع الفاعل الأصلي('). 


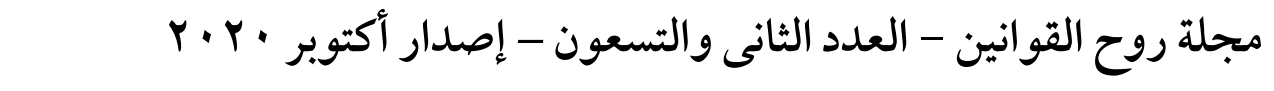
ويتم الاختراق غالبا عن طرق الكترونية وذلك باستخدام كلمة سر حقيقية وصحيحة لا يحق للجاني استخدامها؛ وقد يتم باستخدام برامج أو شفرة خاصة، سواء من خلال التليفون أو الكمبيوتر أو غيرهما من الأجهزة.

وقد يقف الأمر عند مجرد تشغيل الجهاز المقفل دون موافقة صاحبه والوصول الى الملفات الموجودة بداخله، لكن إن كان نظام المعالجة مقفل فلا تتم جريمة الدخول غير المشروع وإن قامت جريمة الثروع في الدخول. - (الن.

وقد يقوم الجاني بالدخول من حاسبه الثخصي الى حسابات أخرى ويطلع على ما فيها من معلومات مع عدم وجود دائرة مشتركة بينهما؛ وقد يتمثل الدخول في استعمال كارت تشغيل أو تليفون لسحب مبالغ الية من بنك. وقد يتم الدخول بطرق مادية وذلك باقتحام خزانة الملفات وسرقة الهوية الثخصية.

وقد يكون المتهم مسموحا له بالدخول في حدود معينة بأن يحق له الدخول الى أجزاء معينة من النظام دون غيرها، فإذا به يتجاوز الحدود المسموحة ويتجول داخل النظام المعلوماتي بأكمله أو يدخل الى نطاقات لم يسمح له بدخولها، كما هي الحال في موظف الثؤون الإدارية بالاطلاع على البريد الصادر والوارد والمتابعة في حدود 
| 11 - حماية الملكية الفكرية في الأمن السيبراني

معينة دون أن يكون مسموحا له بالدخول الى النظام المالي، فإن تجاوز الحد الدسموح

لله وتعدى الى غيره كان مسؤولا ولو كان النطاق المنوع من ولوجه غير محمي(').

ويتحقق فعل الدخول المحظور متى ولج الجاني الى الكيان المعلوماتي أو بعض

أجزائه، ولا أهمية بعد ذلك للباعث على الدخول، فقد يكون لمجرد التسليةا، وقد يكون بهدف التلاعب والعبث كالقيام بإضافة معطيات جديدة على النظام المعلوماتي القائم، سواء أكانت الدعامة التي أضيفت اليها المعلومات خالية أم مشغولة بالمعلومات، ويستوي أن يقوم بها أي شخص، من خارج النظام المعلوماتي أو من داخله وهو الغالب كالموظف المسؤول عن المحاسبة مثثلا().

ويوجد هذا النمط من أنماط الإجرام المعلوماتي بشأن بطاقات السحب الممغنة، كأن يقوم شخص بسرقتها أو التقاطها بعد فقد صاحبها لها، أو تزويرها، واستخدامها ممن لا يشرع له استخدامها، وكذا بإنخال الفيروسات ونحوها.

ويتحدد النطاق الدكاني للاخول غير الدشروع بالتسلل الى داخل النظام، كما يتحدد النطاق الزماني بتجاوز حدود الفنرة الزمنية السسمح بها لللخول.

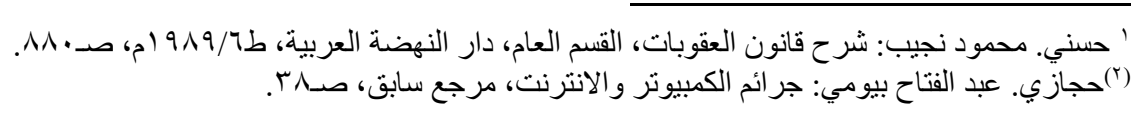


r. r. · مجلة روح القوانين - العدد الثانى والتسعون - إصدار أكتوبر

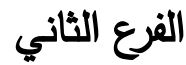

\section{الاعتداءات الخاصة بقيمة المعلومات المعالجة آلياً}

يمكن تقسيمها إلى نوعين منها الواقعة على ذات المعلومات كجرائم الإتلاف والتشويه والتخريب، والسطو على مجالات المليكة الفكرية.

$$
\text { ومن صور الاعتداءات في هذا الصدد ما يلي('). }
$$

\section{1- - تغيير تصاميم الموقع.}

حيث يقوم الجاني باختراق الموقع لتشويهاه وتغيير تصاميمه، كأن يغير تصميم الصـفـحة الرئيسـية متحديا الإجراءات الأمنية للثـبكة بكسـر نظم الحماية، كأن يتم اختراق صفحة رسمية ووضع علم دولة أخرى عليها.

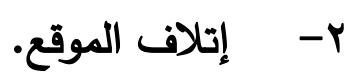

ومعنى الإتلاف إخراج الثـيء من أن يكون منتفعا به منفعة مطلوبة منه عادة، عن طريق قيام الجاني بتعيبيه على نحو يفقده قيمته الكلية أو الجزئية، ويجعله غير

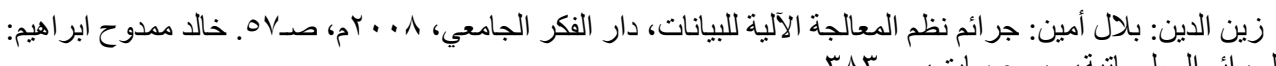

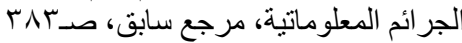


| 11 - حماية الملكية الفكرية في الأمن السيبراني

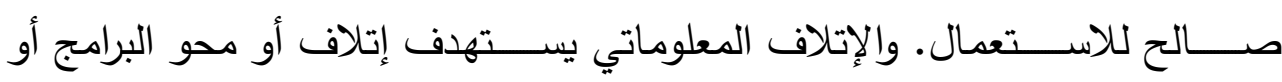

المعلومات والبيانات ذاتها، أو تشويهها على نحو يجعلها غير صالحة للاستعمال.

وإتلاف المواقع أو تدميرها يتم عن طريق الدخول غير المشروع الى نقطة ارتباط

شــبكية بهذف تخريب النظام، وتسـتخدم في إتلاف المواقع وسـائل عديدة، كأن يقوم

الجاني بضخخ آلاف الرسائل الإككترونية الى الموقع المستهدف، للضغط على السعة

التخزينية للموقع، مما يؤدي الى تفجير الموقع وانتقال المعلومات المخزنة إلى جهاز الجاني(")، ويستوي أن يكون الإتلاف كليا أو جزئيا.

ويراعى أن البرامج والمعلومات الدســــلة على دعامات مادية منفصـــلة عن

الحاســب الآلي يكون التعدي عليها من باب إتلاف منقولات الغير ، أو المصــنفات الأدبية له حسب تكييفها، أما البرامج الموجودة على جهاز الحاسب فأن التعدي عليها يكون من باب التعدي المعلوماتي. ويأخذ الإتلاف المعلوماتي صوراً متعدة، فقد يكون ب:

محو البيانات الكترونيا بتدميرها كليا أو جزئيا.

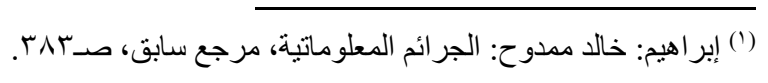
$\{$ \{ 10$\}$ 
r.r. · مجلة روح القوانين - العدد الثانى والتسعون - إصدار أكتوبر

ويحصـــل المحو أو الحذف أو الإتلاف أو التدمير بإزالة جزء من المعلومات

المسجلة على الحاسب ونحوه. وهي تعني البرامج الخبيثة التي تستخدم لإتلاف أنظمة المعالجة الألية للمعلومات، وهي عبارة عن برامج مشـفرة ومصـممة على نحو يجعلها قادرة على التكاثر والانتثـار من مجال الى آخر ، بواسـة الأقراص أو عبر الثـبكة، ولو في أي مكان في العالم، وتسـتهدف الفيروسـات المعلومات المخزنة على الأجهزة المستهدفة لتغييرها أو حذفها أو سرقتها أو نقلها، أو تدميرها كليا أو جزئيا أو تحريفها.

\section{تعديل البيانات أو تغيير مسارها وطرق انتقالها.}

ويكون التعديل أو التغيير أو التزوير بتغيير المعطيات الموجودة داخل النظام واســـتبدالها بأخرى، أو بإدخال بيانات غير مســموح لهم بإدخالها في نظم معالجة البيانات مما يؤدي الى التثـــويش على البيانات الموجودة. ويســــخدم لذلك برامج متخصصـة وقنابل وفيروسـات معلوماتية كحصـان طروادة وفيروس الدودة وهو عبارة عن برنامج معلوماتي له قدرة عالية على تعطيل وإيقاف الحاسـب الآلي كاملا'('. ولا تقف هذه الصور عند حد معين بل هي متجددة وفقا لطبيعة النظام المعلوماتي. 
(1) - حماية الملكية الفكرية في الأمن السيبراني

r- - شغل عنوان الموقع.

وهو من قبيل التعطيل للموقع، أو التعييب، وعن طريق شغل عنوان الموقع يبدو

ظاهرا لأي مســـخدم أن الموقع مشــغول لكثرة الزائرين، في حين أنه إثـــال وهمي بهدف الحجب عن الجمهور ومنعهم من الوصول إليه.

ويستوي في الإشغال ونحوه أن يتم عن طريق الشبكة المعلوماتية الدولية أو عن

طريق شبكة محلية، أو بأي وسيلة من وسـائل تقنية المعلومات لأن الوسـائل في هذا الباب متجددة ولا تقف عند حصر (').

ومن وقع عليه التزام بالحماية أو التأمين للموقع، وتم الاخترق أو الدخول غير

المشـروع فإن الملتزم بتلك الحماية ونحوها يكون مسـؤولا، وهو التزام بتحقيق نتيجة لا

مجرد بذل عناية.

لذا تعد برامج التأمين لحماية معلومات المنظمة أو المنشأة المعنية لـنع أو تقليل المخاطر التي قد تؤثر على توافر المعلومات وسريتها وسلامتها، ذلك أن الأضرار التي تتجم عن قصور وفثل إجراءات الأمن تؤدي إلى خسارة مباشرة تعود بالضرر علي 'سليم د طارق عبد الوهاب: الجر ائم المرتكبة بواسطة الانترنت وسيل مكافتها، تونس 991 م، ص10. $\{\leqslant 7 \gamma)$ 
r. r · مجلة روح القوانين - العدد الثانى والتسعون - إصدار أكتوبر المنظمة المعنية. ومن أهم تلك الخسائر خسارة الاعتمادات أو الملكية الفكرية؛ وكذا خسارة الرغبة في العمل الكفء المتسم بالجودة العالية للعملاء أو الموردين. لذا تصبح مهمة حماية وتأمين البيانات والمعلومات لها الأولوية القصوى والمطلقة في تخطيط وعمل نظم المعلومات على كافة أنواعها وتوجهاتها. الجدير بالذكر أن حماية الملكية الفكرية هي المرجع والأساس القانوني في حماية برامج الحاسوب والبيانات وبرامج الحاسوب لأن هذه البرامج لا تخرج عن كونها إنتاجات فكرية، وعلى الرغم من ذلك فقد جرى العمل على إيجاد أنظمة خاصة تحمي هذه البرامج المعلوماتية، دون الوقوف عند حد أنظمة حماية حق المؤلف، فعلى الرغم من أن قوانين حماية حق المؤلف وحقوق الملكية الفكرية والصناعية قد تلبي حاجة حمايتبرامج الحاسوب والبرمجيات، إلا أن تخصيص أنظمة لحماية هذه الحقوق في مجال الفضاءالسيبراني هو الأكمل، لأن التخصيص يراعي مختلف الحالات التي تتفرد فيها حقوق الملكية الفكرية في الفضاء السيبراني('). فحماية تلك البرامج من خلال حقوق الملكية الفكرية يحفظ حق إعادة الإنتاج من خلال إعطاء الحق الحصري بالترخيص أو منعه بشكل مباشر أو غير مباشر، وإعطاء 
11

المؤلفين الحق بترخيص أو منعترخيص إيصال الأعمال إلى الجمهور سلكياً أو لاسلكياً،

كما يحفظ حق التوزيع بإعطاء الحق للمؤلفين بترخيص أو منع ترخيص توزيع أعمالهم. كما توفر الحماية القانونية ضد الاستعمال غير المشروع لحقإدارة المعلومات(').

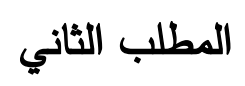

\section{الاعتداءات الخاصة بحقوق الملكية الأدبية والفكرية لبرامج الحاسب ونظمه}

يتاول هذا المطلب بيان الاعتداءات المتعلقة بالنصب والاحتيال في عالم النشر، وكذا الاعتداءات المتعلقة بالحصول على مال الغير عن طريق الغش المعلوماتي (بطاقات الائتمان ونحوها)، وذلك من خلال بيان صور هذه الاعتداءات والتعريج على

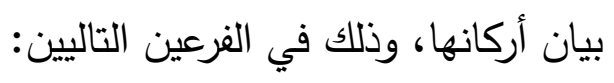


r. r. · مجلة روح القوانين - العدد الثانى والتسعون - إصدار أكتوبر الفرع الأول الاعتداءات المتعلقة بالنصب والاحتيال في عالم النشر

ويراد بالنصب المعلوماتي هو سلوك طرق احتيالية عبر الوسائل الإكترونية بغية الحصول على مال أو ما في حكمه.

حيث تقوم هذه الجريمة كغيرهـا من الجرائم على ركنين مادي ومعنوي؛ ويتمثل الركن المادي في الوسائل التي يتخذها الجاني في سبيل تحقيق النتيجة الاجرامية التي يرمي الى تحقيقها ليسـتولي لنفســه أو لغيره على مال منقول في حيازة الغير أو على سند، أو توقيع هذا السند، وقد أشارت المادة محل الشرح الى جانب من تلك الوسـائل بقولها: "وذلك عن طريق الاحتيال، أو اتخاذ اســــ كاذب، أو انتحال صـــفة غير صحيحة".

أما الركن المعنوي فيقوم وفقا للمادة محل الثـرح على قصـــ عام وقصــ خاص، فالقصد العام هو علم الجاني بأنه يأتي أعمالا وادعاءات مكذوبة تشكل مجافاة للحقيقة وتغييرا لها، وأن تتجه ارادته الى ارتكاب السلوك الاجرامي وهو سلب مال الغير ونحوه من ماديات الجريمة المقررة في المادة محل الثــرح، وأن يعلم أن هذه الوســـائل من $\varepsilon \vee \cdot)$ 
11 - 11

شأنها خداع المجني عليه وحمله على تسليم ماله، وأن يتوافر له القصد المعاصر وقت

الاستيلاء أو التلاعب، أما القصد اللاحق فلا عبرة به(').

ومن صـور الاعتداء على الأعمال الإككترونية النســخ غير الثـــعي، وسـرقة

المعلومات، وسرقة البرامج، إضافة إلى التنمير والإتلاف ونحوها.

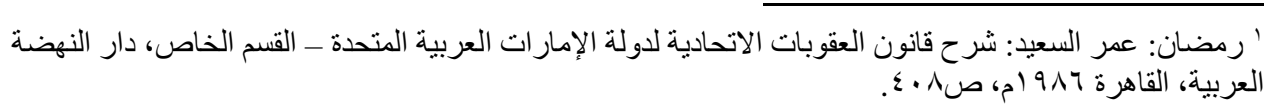


r. r. · مجلة روح القوانين - العدد الثانى والتسعون - إصدار أكتوبر

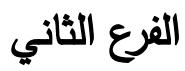

الاعتداءات المتعلة بالحصول على مال الغير عن طريق الغش المعلوماتي

(بطاقات الاتتمان ونحوها)

تتنوع صور الاعتداء على تلك البطاقات ونحوها حيث يتصور استخدامها من قبل غير صاحب الحق بعد سرقتها أو سرقة الأرقام السرية الخاصة بها، وهو ما يتم عن طريق اختراق بعض المواقع التجارية التي يمكن أن تسجل عليها أرقام هذه البطاقات. فهناك جرائم معلوماتية تستهدف مراكز معالجة البيانات والمعلومات المختزنة على أجهزة الحاســـوب لاســـتخدامها بطريقة غير مشـــروعة، كالولوج الى أحد الأنظمة للحصــول على أرقام بطاقات الائتمان ذات الدفع الالكتروني للاسـتيلاء على أرقامها وشفرتها وتقليدها للحصول على مبالغ من حساب مالكيها (1). أو من خلال استخدام بطاقات الدفع الالكتروني المزورة، حيث يقوم المجرم المعلوماتي بتقليد برامج التشغيل، أو الحصـول على هذه الأرقام والتقاطها عبر قنوات الانترنت واسـتخدامها، حيث يقوم العميل بالاخول الى موقع التاجر على الثـــبكة المعلوماتية ويشـتري الســلـع ثم يقدم

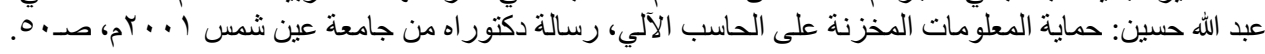
$\varepsilon \vee r$ 
11

بطاقة الائتمان التي زورها، مما يتعين معه وضع حماية فاعلة لتلك البرامج والبطاقات وحمايتها من الدخول غير المصرح وفلك شفرتها وتقليدها.

وتقع تلك الاعتداءات على مـا تمثله المعلومات والبيانات المعالجة آليا، والتي تســتهدف الحصــول على مال الغير شــرعي عن طريق الغش والنصــب والاحتيال بالحاسب الآلي (كالتعدي على بطاقات الائتمان).

فقد ترتب على شيوع التعاملات الإلكترونية ضرورة إجراء التحويلات والمبادلات المالية حول العالم من خلال البطاقات الائمانية ونحوها، وهذا وإن ســـل المعاملات إلا أن له مخاطره التي تكمن في إمكانية التلاعب في البيانات المخزنة في الحاسـوب ونحوها، وإجراء تحويلات للأرصدة أو لبعض منها، بمجرد الوصول الى كلمة المرور الخاصة بالحساب المجني عليه.

ويحصل المجرم المعلوماتي على كلمة المرور الخاصـة بالمجني عليه بالتقاطها

أثناء التواجد في النظام المعلوماتي، ســـواء أكان عاملا في مجال إدخال البيانات، أو متواجدا على الثـــبكة أثناء تبادل تلك المعلومات، أو من خلال البرامج التي تســرق

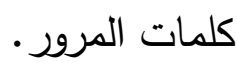




$$
\text { r.r. · مجلة روح القوانين - العدد الثانى والتسعون - إصدار أكتوبر }
$$

وتقوم هذه الجريمة على عدد من أشكال التنكر والخفاء والتعمية التي تعمل على

خداع الطرف الآخر وجعله يتقبل المعلومات الخاطئة أو المزيفة، ومن ذلك سرقة هوية شـخص آخر واستخدام اسـمه أو رقمه الوطني أو بطاقته الائتـانية أو أرقام حسـاباته ليقوم بالســــب النقدي أو تحويل مبالغ مالية أو تســـــيل مشــــريات على بطاقة الائتمانات أو تحرير شـــيكات أو نحو ذلك؛ وفي هذه الحالات لا تتوف الجريمة عند مجرد الخســـارة المالية بل تتعدى الى الجانب المعنوي الذي يشــــل الاطلاع على حسابات ومعلومات الضحية. ويشتمل الركن المادي لهذه الجريمة على عناصر ثلاثة هي:

1- اســـخدام الجاني لوسـائل الخداع والتدليس المنصــوص عليها على سـبيل الحصر ، وهي الاحتيال واستخدام اسم كاذب وانتحال صفة غير حقيقية. r- نتيجة إجرامية أو أثر للنشـاط الإجرامي يتمثل في تسليم المال المنقول الى

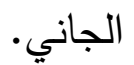


ا 11 - حماية الملكية الفكرية في الأمن السيبراني

طرق الاستيلاء على المال المنقول.

يتم الاســـيلاء على المال المنقول من خلال عدة طرق أوردها النظام(')وهي الاحتيال أو اتخاذ اسم كاذب أو انتحال صفة غير صحيحة.

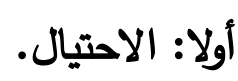

والاحتيال هو: كل تظاهر أو إيحاء يكون صـالحا لإيقاع المني عليه في الغلط

بطريقة تؤدي الى الاقتناع المباشـــر بالمظهر المادي الخارجي، ويكون المجني عليه هو: من جازت عليه حيلة الجاني فانخدع بها وسلمه ماله(؟).

ومن أســاليب الاحتيال أن يقنعه بوجود مشــاريع وهمية وكاذبة، أو يعرض له

مشروعا حقيقا ويقنعه بأرباح وهمية، أو قيام محتالين بإنشاء تأمينات بنكية وهية، أو نشـر وإعلان مواقع تتعلق بتجارة ســـع أو تقديم خدمات وهمية، أو يوهمها بوجود ســــ دين غير صحيح أو سند مخالفة مزور ونحو ذلك؛ فيتصيدون أموال الناس عن طريق

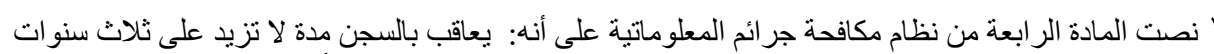

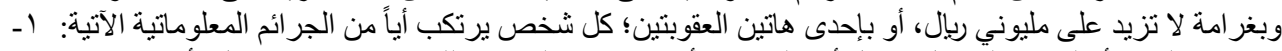

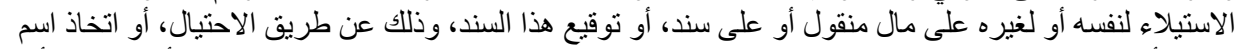

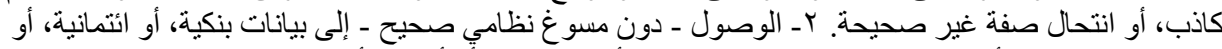

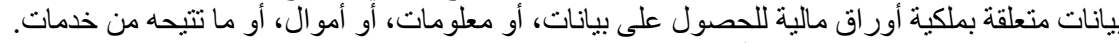

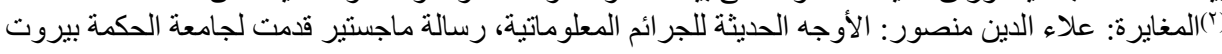


r. r · مجلة روح القوانين - العدد الثانى والتسعون - إصدار أكتوبر وسـائل الدفع المختلفة والتي من أهمها بطاقات الائتمان، وقد يسـتغل موظفو البنوك والثركات النظام المعلوماتي لتلك المؤسسات للوصول الى الكسب المالي عن طريق عقد صفقات زائفة والعبث بأنظمة المعلومات.

وقد يحصــل المجرم المعلوماتي على هوية المســتخدم الحقيقي للجهاز بطريق غير مشروع ويتعامل مع الجهاز على أنه المستخدم الحقيقي حتى يحصل على الثفرة الخاصـة بالتشـغيل ويقوم بعملية تحويل الأموال والاستيلاء عليها بالاحتيال. والتحايل يقع على الثخص الطبيعي والثخص المعنوي('). وهناك برامج تعمل على خصــــم مبالغ قليلة القيمة من حســـابات الفوائد على الودائع المصرفية، وذلك بإغفال الكسور العشرية فقط، حيث يتحول الفارق مباشرة الى حسـاب الجاني، ورغم ضـخامة المحصلة، إلا أنه يصـب اكتثـافها لأنها تعتمد على التكرار الآلي لمعالجة معينة، مع ضـآلة المبلغ المخصـوم من كل حسـاب على نحو 
11

يصـسب معه تتبه العميل إليه(')ومن أشــهر وسـائل الاحتيال تصــميم برامج تقوم

بعمليات التحويل الآلي من حساب لآخر.

وصــدر تقرير عن إدارة العدالة الأمريكية عام ب^ه ام بعنوان جرائم الحاسـبـ

الآلي نظم التحويل الالكتروني للأموال(†) ومن هذه الوسائل:

1- التلاعب في المكونـات المـادية لنظم التحويل الالكتروني للأموال، ويتضــــن ذلك

اســتعمال خطوط الاتصـــال لخلق أو تدمير البيانات أو الطلبات الخاصـــة بعمليات

التحويل.

r- اســتعمال البرامج الخاصـــة بنظم التحويل الالكتروني للأموال والتتلاعب بها بغرض البدء في إجراء عملية تحويل غير مشروعة أو بغرض إخفائها.

r- التلاعب عن طريق إصدار بطاقات ائتمان مزدوجة.

ع - استخدام بطاقة شخص آخر لسحب مبالغ نقدية من الرصيد الخاص بصاحب البطاقة.

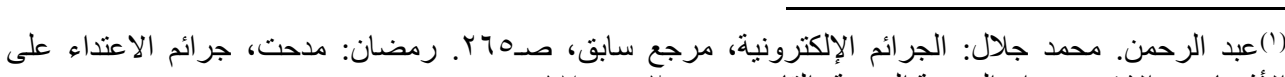

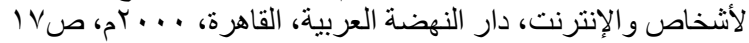

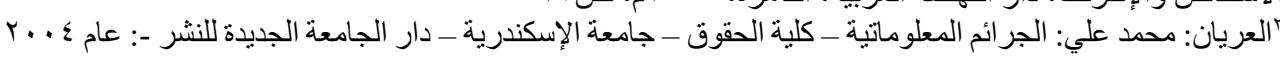




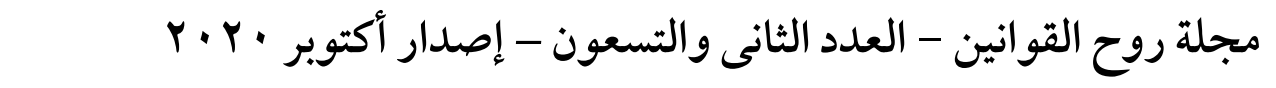
ه- استخدام أسلوب تقليدي في ارتكاب الجريمة مثل كسر ماكينة الصرف الآلي وسرقة ما بها من أموال. ويشترط في الطرق الاحتيالية أن تحتف وتقترن بادعاءات كاذبة من شأنها خداع المجني عليه وحمله على تسليم المال المنقول أو السند أو التوقيع أو الغائه أو اتلافه أو تعديله، كما يشترط أن تكون تلك الادعاءات مدعومة بمظاهر خارجية من شأنها ايهام المجني عليه وايقاعه في شرك الاحتيال؛ ومن تلك الأعمال الاحتيالية التلاعب في المعلومات واخراجها بشكل غير صحيح، وكذا استخدام الفيروسات للاضرار بذاكرة الحاسوب على نحو يغير أو يحرف في البيانات. الوسائل الفنية للتحويل الالكتروني للأموال. يتم تحويل الأموال إلكترونيا عبر وسائل منها ما يلي: 1- استخدام برامج معدة لتتفيذ الاختلاس. r- التحويل المباشر للأرصدة. التلاعب بالبطاقات المالية. 
11 - 11

حيث تتنوع صور الاعتداء على تلك البطاقات حيث يتصور استخامها من قبل

غير صاحب الحق بعد سرقتها أو سرقة الأرقام السرية الخاصة بها، وهو ما يتم عن

طريق اختراق بعض المواقع التجارية التي يمكن أن تسل عليها أرقام هذه البطاقات.

$$
\text { وهناك جريمة الاستيلاء على النقود الإلكترونية }
$$

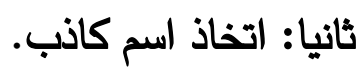

من الطرق التي يسلكها المجرم المعلوماتي للاستيلاء على المال المنقول اتخاذ اسم كاذب، ويشمل ذلك اتخاذ اسم فرد أو اتخاذ اسم موقع ونحو ذلك من البيانات الكاذبة التي تعمل على إيهام الحاسب والاحتيال عليه فيسلم المال(').

فيلجأ الدجرم المعلوماتي الى جمع المعلومات الثخصية عن الدجني عليه، وينتحل شخصيته ليستولي على الرصيد البنكي، أو يسب من بطاقته الاتثمانية() وقد يحوز البطاقة الايتمانية ورقهها السري بالفقد أو السرقة ويستعمها على أساس أنه

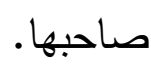

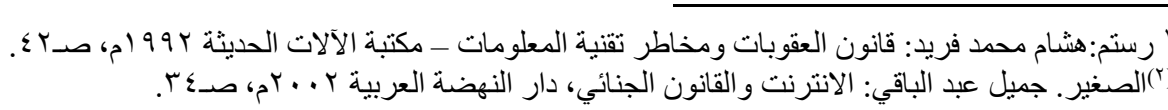




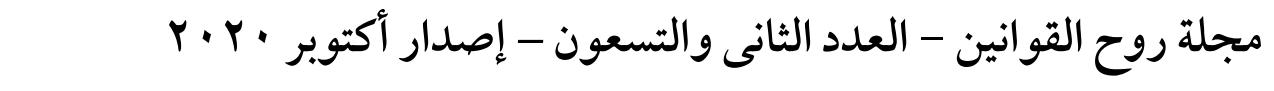
وقد ينشئ المجرم المعلوماتي موقعا وهميا على الثبكة على غرار الشركات والمؤسسات الفعلية، بحيث يظهر في صورة الموقع الفعلي لدقدم الخدمة.

ثالثا: انتحال صفة غير صحيحة(').

من الطرق التي يسلكها المجرم المعلوماتي للاستيلاء على المال المنقول انتحال صفة غير صحيحة. وهذه الجريمة كسابقتها من جرائم النصب أو التزوير المستحدثة. فعلى سبيل المثال تستخدم البنوك والمؤسسات المالية الثبكة العالمية في تعاملاتها المالية، ويتم دخول العملاء على صفحة المؤسسة وإبرام التعامل معها، وتظل تلك الطرق في التعامل عرضة لانتهاك المخربين حيث يعملون على انتحال صفة المستخدم الثرعي والتصرف على أساس أنه صاحب الهوية على خلاف الحقيقة.

وانتحال المواقع الإكترونية وتحويل الاتصالات من على الموقع الأصلي إلى المزيف يتم من خلال برامج تصمم لهذا الهدف، وتؤدي الى انتقال كافة المعلومات والمحررات الى سيطرة من قام بانتحال الموقع الالكتروني.

' داود: حسن طاهر: جر ائم نظم المعلومات، أكاديمية نايف العربية للعلوم الأمنية، الرياض، ...T، صـبTr. $\{1$. $)$ 
| 11 - حماية الملكية الفكرية في الأمن السيبراني

ومن أمثلة ذلك أن يقوم شخص بالدول على الحاسب الآلي الخاص بغيره، وقام

بإنجاز تصرف معين من خلال استخدام البرامج الخاصة بصاحب الحاسوب، مما أدى

إلى إتمام معاملة أو إبرام تصرف بشكل غير مطلوب أو مخالف للحقيقة.

ومن الصور الاستيلاء على البطاقة الايتمانية لثخص فقدها أو بالسرقة منه،

مدعيا أنها له، ثم يقوم بسحب مبالغ مالية منتحلا صفة الغير.

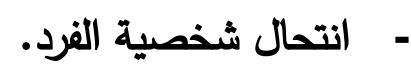

ويتم ذلك من خلال تجميع المعلومات والبيانات عن الشخص المجني عليه، كأن

يقوم المجرم بالإعلان عن جائزة قيمة لمن يذخل الى الموقع ويوم بالاشتراك فيه، ودفع

رسوم رمزية لجهة خيرية مثلا، وهذا يقتضي الإفصاح عن بعض البيانات الشخصية،

كالاسم والعنوان ورقم بطاقة الآتمان لخصم المبلغ المطلوب، فيقوم الجاني بالاستيلاء

على الرصيد البنكي أو السحب من البطاقة الايتمانية من خلال البرامج الاحتيالية('). 
r. r. · مجلة روح القوانين - العدد الثانى والتسعون - إصدار أكتوبر

ويتم الاحتيال عادة عن طريق سرقة أو تخمين الأسماء وكلمات المرور، وعندما ينتحل شخص شخصية غيره فإنه يستطيع أن يفعل ما يفعله صاحب الثخصية الفعلية، ويمكن للمحتال المنتحل لصفة غيره أن يؤذي صاحب النظام بإرسال رسائل سيئة باسمه أو يدمر سمعته المالية أو الثخصية. -

وهو أشد خطورة من انتحال شخصية الفرد، كأن يقوم المجرم المعلوماتي باختراق الموقع المجني عليه، ثم يوم بتصميم البرنامج الخاص به، ويضعه على صفحة موقعه مما يؤدي الى توجه الباحث عن الموقع الى الموقع المزور بمجرد كتابة الاسم على

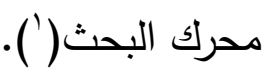

$$
\text { ' الأردناعسة، أسامة أحمد: جرائم الحاسب الآلي و الإنترنت، دراسة تحليلية مقارنة، طا دار و ائل للنشر عمان }
$$


11 - I - مماية الملكية الفكرية في الأمن السيبراني

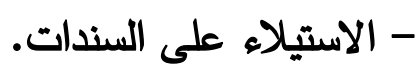

والسندات هي الصكوك التي تنشئ حقا أو تثبت انضضائه، كصكوك الدين

والدخالصات ووثائق الزواج والطلاق، وأذون الاستيراد والتصدير والعقود، ونحوها. ويتم

ذلك بالاحتيال أو اتخاذ اسم كاذب أو انتحال صفة غير صحيحة (1).

الجريمة الثانية: وصول المجرم المعلوماتي - دون مسوغ نظامي صحيح - إلى بيانات

بنكية، أو ائتمانية، أو بيانات متعلقة بملكية أوراق مالية للحصول على بيانات، أو معلومات، أو أموال، أو ما تتيحه من خذمات.

ويعرف هذا النوع من الجرائم بجرائم البطاقات المغنطة، أو جرائم النقود

الإلكترونية، وهي عبارة عن قيمة نقدية مختزنة بطريقة الكترونية على وسيلة الكترونية

وتكون مقبولة كوسيلة دفع للتعامل بين الجمهور، بواسطة متعهدين، حيث يتم وضعها

في متناول المستخدمين لاستعمالها كبديل عن العملات النقدية والورقية؛ أو هي مخزون

الكتروني لقيم نقدية على وسيلة تتنية تستهدف القيام بدفوعات لمتعهدين دون حاجة

(1) قنديل. سعيد السيد: التوقيع الالكتروني، ماهيته وصورهو وحجيته في الإثبات بين التدويل والاقتباس، دار الجامعة

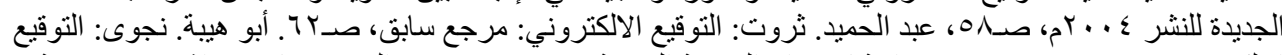

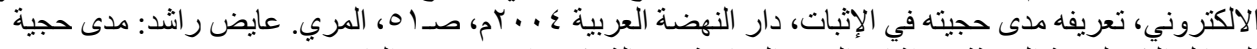

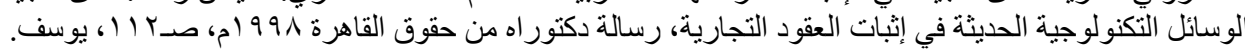

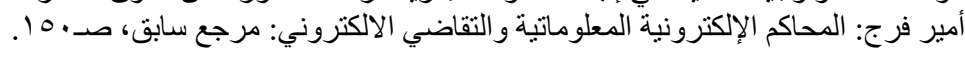


r. r · مجلة روح القوانين - العدد الثانى والتسعون - إصدار أكتوبر الى وجود حساب بنكي عند اجراء الصفقة وتستخدم كأداة محمولة مدفوعة مقدما، ولذا

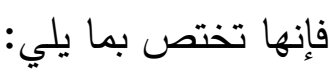

ولهذا النوع من النقود في المجتمعات الحديثة شأنا عمليا كبيرا وعلى مستوى الأفراد أصبحت من متطلبات السفر والترحال. ذلك أنها تحقق للإنسان أمانا على أمواله حال حملها معه، فتتعرض للفقد أو السرقة، وكنلك يتمكن بها من شراء ما يبدو له شراؤه في ظروف مفاجئة لم يستعد لها بحمل ما يكفي لهذه المشتريات، فضلا عن أن البطاقة تيسر لحاملها السداد بأي عملة دون أن يحتاج لحمل العملات المختلفة التي توجد إجراءات للخولها وخروجها في بعض البلاد التي بها قيود على تحويل العملة، ثم إنها تشكل وسيلة للمحاسبة وضبط المصاريف وتوثيق السداد للمطالبات. وهذه البطاقات على أنواع:

1- بطاقة السحب الآلي، ومن خلالها يستطيع حاملها سحب المبالغ النقدية من حسابه من

خلال أجهزة السحب الآلي، بحد أقصى مقرر ('). 
| 11 - حماية الملكية الفكرية في الأمن السيبراني

r- بطاقة الثيكات، ومن خلالها يتعها البنك الذي أصدرها لحاملها بسداد الشيكات التي لإليه

يحررها العميل من البنك وفقا لشروط إصدارها(').

r- بطاقة الائتمان، وتخول حاملها الحق في الحصول على التسهيلات الائمانية من

مصدرها، بحيث يمكنه الحصول بموجبها على السلع والذذمات، ثم تقوم الجهة الصصدرة

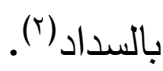

ع - بطاقة الوفاء، وهي التي يكون لحاملها رصيد بالبنك فيسحب منه مباشرة قيمة مشترياته

وأجور الخدمات المقدمة له، في حدود الرصيد الموجود، ويتم الحسم منه فورا، ولا

يحصل صاحبها على إقراض(r).

وتحتوي هذه البطاقات على شريط ممغنط تخزن فيه البيانات الثخصية لحامل

البطاقة، وبيانات مصدرها، وبيانات البطاقة نفسها، بل هناك نوع من البطاقات يشتمل

على ذاكرة أو دوائر الكترونية تسمح بتخزين آلاف البيانات().

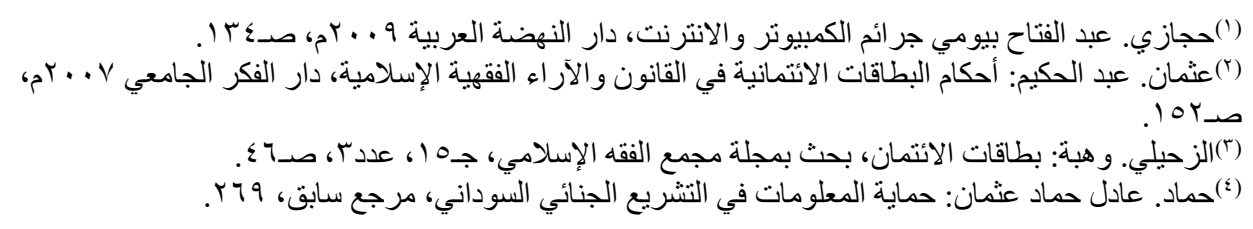

s 10 
r. r · مجلة روح القوانين - العدد الثانى والتسعون - إصدار أكتوبر

ويتمثل النشاط الإجرامي المقرة في الفقرة محل الثرح في وصول المجرم المعلوماتي

- دون مسوغ نظامي صحيح - إلى بيانات بنكية، أو ائتمانية، أو بيانات متعلقة بملكية أوراق مالية للحصول على بيانات، أو معلومات، أو أموال، أو ما تتيحه من خدمات.

\section{ومن صور الجريمة المذكورة ما يلي:}

1- حصول شخص على بطاقة ائتمان صحيحة بناء على مستتدات مزورة، حيث يتقدم الجاني الى البنك بمستندات غير صحيحة كأن ينتحل فيها صفة الغير مثلا، أو يعتمد على بيانات كاذبة، فتصدر له البطاقة ويستخدمها في شراء السلع والخدمات، ولا يتمكن البنك من استرداد القيمة بعد ذلك لعد الاستدلال على صاحب البطاقة أو لعدم كفاية

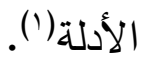

r- استعمال البطاقة بعد انتهاء مدتها أو رغم إلغاء البنك لها.

r- حصول الغير على البطاقة كما لو فقدت أو سرقت، وحصوله على الرقم السري لها. 
11 - - حماية الملكية الفكرية في الأمن السيبراني

ع- اتفاق موظف البنك مصدر البطاقة مع حاملها على استخراجها ببيانات مزورة، أو

السماح للعميل بالسحب بما يتجاوز حد البطاقة، أو اتفاق موظف البنك مع التاجر على

اعتماد إنعارات بيع صدرت الى بطاقة وهية أو مزورة أو منتهية الصلاحية.

ه- قبول التاجر استخدام بطاقات ليست لها أرصدة كافية للصرف، أو قبول البطاقات

المزورة من العملاء، بالتلاعب في البرامج الخاصة بالماكينة الإلكترونية بحيث لا

$$
\text { تكثيف التزوير (1). }
$$

4- حصول القراصنة على بيانات بطاقات الدفع الآكتروني واستعمالها بطرق غير مشروعة

للحصول على السلح والخمات، سواء تم ذلك الحصول بطريق الاختراق لخطوط

الاتصالات التي تربط بين العميل والتاجر، أو عن طريق الخداع بإنشاء مواقع وهمية

على غرار المواقع الفعلية، أو عن طريق إنثاء أرقام بطاقات من خلال معادلات

رياضية في تبديل وتوفيق الأرقام للحصول في النهاية على رقم سري أو كود خاص

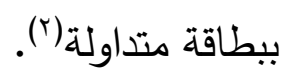

(') حجازي. عبد الفتاح بيومي: التجارة الإلكترونية وحمايتها القانونية، الكتاب الأول، صدV 1 أ.

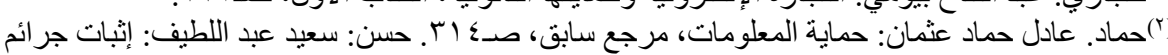

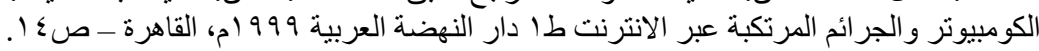

$\varepsilon \wedge V$ 
r.r. • مجلة روح القوانين - العدد الثانى والتسعون - إصدار أكتوبر وتكمن الحماية القانونية لبرمجيات الحاسوب المقررة بموجب قانون براءات الاختراع. تتعلق بالبرمجيات التي لديها مفعول تقني أو صناعي أي التي تؤدي دورأ تقنيا أو صناعياً، وهي برامج تتميز بالتحليل والتصميم والترميز والتكامل والتوثيق. وهذا الأخير مرحلة هامة من مراحل بناء النظام البرمجي حيث يتم توثيق البناء الداخلي للبرنامج، وذلك بغرض الصيانة والتطوير ، وهناك أكثر من طريقة للتوثيق أهها توثيق المبرمج وذلك بإضافة تعليقات داخل الثفرة البرمجية. إن مؤلف العمل الرقمي سواء أكان هذا العمل برنامجاً للحاسوب أو قاعدة بيانات أو تصميماً هندسياً جديداً، لم يعد نتيجة عمل فرد واحد، بل يغلب أن يكون عمل عدد من المبتكرين، لذا وجب حماية الأعمال الرقمية من التعدي، بأن تنزل الأعمال الرقمية منزلة الأعمال الذهنية المبتكرة لأجل حمايتها بواسطة أنظمة حماية الملكية الفكرية. وتتطلب حماية الأعمال الرقمية من برامج وقواعد بيانات بموجب أنظمة حماية امللكية الفكرية على اعتبارها أعمالا ذهنية ضرورة مراجعة تلك الأنظمة والعمل على تعديلها لتشمل الأعمال الرقمية، كما يتعين توسيع نطاق تطبيق المعاهدات الدولية الخاصة بحماية الملكية الفكرية لتشمل الأعمال الرقمية. 
11

المبحث الثالث

\section{وسائل حماية الملكية الفكرية في الأمن السيراني}

تتضــمن وســائل حماية الملكية الفكرية في الأمن السـيبراني الحماية الإلكترونية

$$
\text { والحماية التنظيمية أو القانونية. }
$$

وتقوم الحماية الإكترونية على حماية الأنظمة المتصـــلـة بالإنترنت مثل الأجهزة

والبرامج والبيانات من التهديدات السيبرانية، لمنع الوصول غير المصرح به إلى مراكز

البيانات والأنظمة المحوسـبة الأخرى، وذلك من خلال توفير وضـع أمني جيد لأجهزة الكمبيوتر والخوادم والثـــبكات والأجهزة المحمولة والبيانات المخزنة على هذه الأجهزة

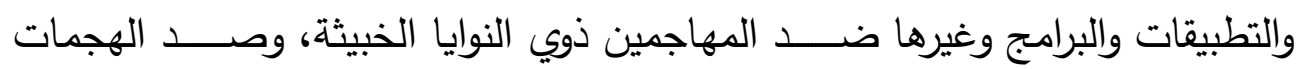
الإكترونية للوصول إلى البيانات الحساسة للمؤسسة أو المستخدم أو حذفها أو تقليدها ونحو ذلك.

إضافة إلى وسائل الحماية القانونية، ونتناول فيما يلي بيان تلك الوسائل على النحو 


$$
\text { مجلة روح القوانين - العدد الثانى والتسعون - إصدار أكتوبر ·. المطلب الأول }
$$

\section{وسائل الحماية الإلكترونية}

يعد الأمن السيبراني مهماً ومع نمو حجم وتعقيد الهجمات الإلكترونية، فإنه يتعين على الشركات والمؤسسات وخاصة تلك المكلفة بحماية المعلومات المتعلقة بالأمن القومي أو الصحة أو السجلات المالية، اتخاذ خطوات لحماية معلومات الأعمال والموظفين الحساسة الخاصة بهر. ويراعى أن التحدي الأكثر صعوبة في الأمن السيبراني هو الطبيعة المتطورة باستمرار للمخاطر الأمنية نفسها، وهذا يقضي بتطوير أنظمة الحماية، وتتمثل وسائل الحماية الإلكترونية في إجراءات متعددة منها ('): أولا: تطوير منظومة أمن الفضاء السيبراني وتأمين البني التحتية للاتصالات وتكنولوجيا المعلومات وذلك بإعداد وتفعيل ما يعرف بفرق الاستجابة لطوارئ الحواسب أو فرق مواجهة حوادث أمن الحاسوب، في القطاعات الحيوية لمواجهة أية أخطار سييرانية أو هجمات سيبرانية توجه اليها، وعن التوعية(ب). ' أحمد: هلالي عبد اللاه: اتفاقية بودابست لمكافحة جر ائم المعلوماتية (معلقا عليها)، طا دار النهضة العربية V. . YTم،

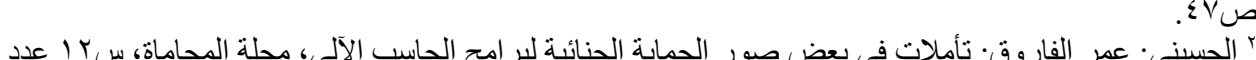

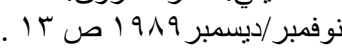


| 11 - حماية الملكية الفكرية في الأمن السيبراني

ثانيا: تفعيل برامج حماية الهوية الرقمية مثل بنية المفتاح المعلن التي يعتد عليها

التوقيع الإلكتروني مما يؤدي إلى توفير متطلبات الأمن السيبراني والتقليل من المخاطر السيبرانية والتهديدات الداخلية والخارجية من خلال التركيز على الأهداف الأساسية للحماية وهي: سرية المعلومات، وسلامتها، وتوافرها. كما يدل في هذه التقنية التعمية أو التشفير بشكل عام هو عملية الحفاظ على سرية المعلومات (الثابت منها والمتحرك) باستخدام برامج لها القدرة على تحويل وترجمة تلك المعلومات الى رموز بحيث إذا ما تم الوصول إليها من قبل أشخاص غير مخول لهم بذلك لا يستطيعون فهم أي شئ لأن ما يظهر لهم هو خليط من الرموز والأرقام والحروف الغير مفهومة، يتم تشفير الملف وفاك التشفير عن طريق آلمة السر، التي يجب ان تكون معروفة للطرفين (المرسل والمستقبل) وهذا ما يسمى بالتثفير

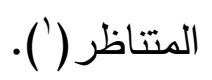
كما يجب التأكد الدوري من أمن الثبكة لحماية الثبكة من المستخمين غير المرغوب فيهم والهجمات والاقتحامات. وكذا أمان التطبيق بالعمل على توفير تحديثات 
r. r · مجلة روح القوانين - العدد الثانى والتسعون - إصدار أكتوبر واختبارات مستمرة للتأكد من أن هذه البرامج آمنة من الهجمات. فضلا عن الاهتمام بالتعافي من الكوارث والتخطيط لاستمرارية الأعمال في حالة الهجوم والتعدي وقد أثبت نظام التشفير فعاليته، ففي نطاق التوقيع الإلكتروني مثلا نجد التشفير يعتمد على مفتاح خاص وآخر عام، تصدرهما الثركة المختصة بإصدار التوقيع الأكتروني؛ فالمفتاح الخاص عبارة عن أداة الكترونية خاصة بصاحبها ولا تتكرر كالبصمة، وتتشأ بواسطة عملية حسابية خاصة، ومن خلاله يوضع التوقيع الالكتروني على المحرر الالكتروني، ثم يحفظ ذلك المحرر في بطاقة ذكية مؤمنة، فإذا رغب الثخص في التعاقد إلكترونيا فعليه أن يقوم بكتابة رسالته وتوقيعها الكترونيا باستخدام مفتاحه الخاص، ثم تمريرها من خلال برنامج خاص بالتشفير في الحاسب الآلي، حيث يقوم هذا البرنامج بتثفير المعاملة بعمليات حسابية معقدة تحول الرسالة المكتوبة إلى رقمية، ثم يأتي بعد ذلك دور المفتاح العام. والمفتاح العام لا بد منه لفك شفرة الرسالة المرسلة من صاحب المفتاح الخاص، ليقوم البرنامج الخاص بالمستقبل بإرسال نسخة من التوقيع الاككتروني إلى الجهة التي أصدرت الشهادة، لتقوم أجهزة تلك الهيئة بمراجعة قاعدة البيانات الخاصة بها، والتعرف على صحة التوقيع، ثم إعادة النتيجة والمعلومات الخاصة بالثهادة إلى المستقبل، ليقوم 
( 11 - حماية الملكية الفكرية في الأمن السيبراني

بقراءة تلك الرسالة مستخدما المفتاح العام، ثم يعاود التواصل مع المرسل مكررا نفس الطريقة؛ ومن ثم فالمفتاح العام وإن كان مختصا بشخص لكنه معلن للكافة، ويستخدم في التحقق من شخصية الموقع على المحرر الالكتروني للتأكد من سلامة المحرر والتوقيع، ويوضع رقم سري على الشريحة لئلا تستخدم من الغير حال ضياعها أو

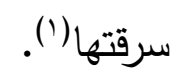

لذا يسعى المبدعون والمبتكرون في مجال الأمن السيبراني إلى تطوير أنظمة البرمجيات والثبكات ومراكز البيانات من خلال البحث عن نقاط الضعف والمخاطر في الأجهز والبرامج وإيجاد أفضل طريقة لتأمين البنية التحتية لتكنولوجيا المعلومات ببناء جدران الحماية في البنية التحتية للشبكة والمراقبة المستمرة للهجمات والاقتحامات

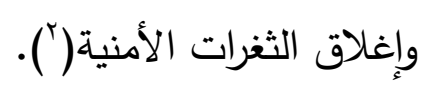

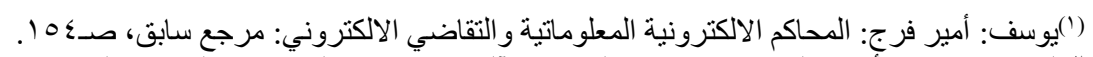

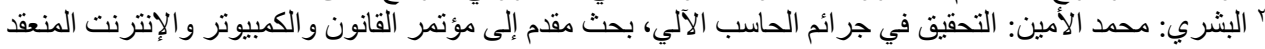

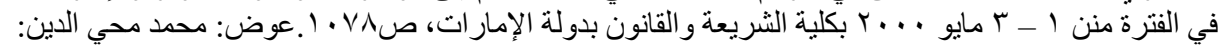

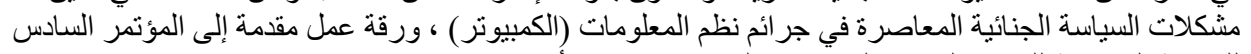

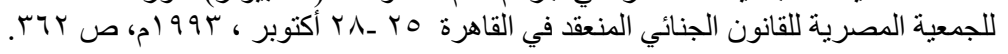


r. r · مجلة روح القوانين - العدد الثانى والتسعون - إصدار أكتوبر المطلب الثاني

\section{وسائل الحماية في التشريعات القانونية}

إن وجود أي فراغ تشريعي بشأن التعديات السيبرانية، قد يضر ضرراً بالغاً

بمنظومة المعاملات والخدمات الإلكترونية مما يتعين معاه وضع النصوص القانونية لحماية الملكية الفكرية في مجال الأمن السيبراني.

وقد وضعت الاتفاقيات الدولية لحماية الدصنفات الرقمية وبرامج الأمن السيبراني،

ومن ذلك الاتفاقيات الدولية المبرمة لحماية الملكية الفكرية بكافة أشكالها كاتفاقية برنلحماية الدصنفات الأدبية والفنية والتي انضمت إليها المملكة العربية السعودية، وهي أهم هذه الاتفاقيات لثرائها وشدة أحكامها فيما يخص حقوق المؤلف، فضلا عن تطورها ومواكبتها لكل ما هو جديد في عالم التقنية والمعرفة.

ثم تأتي اتفاقية تربس للتدابير المتعلقة بأثر التجارة على حقوق الملكية الفكرية، التي أبرمت عام ؟99 (ام، وقد تضمنت قواعد خاصة في مجال حماية المصنفات الرقمية، 
| 11 - حماية الملكية الفكرية في الأمن السيبراني

ثم كانت اتفاقية الويبو لحماية حقوق التأليف التي أبرمت عام 997 1م، وقد أولت هذه

الاتفاقية اهتماما خاصا بالوسائط الإكترونية(1).

وتهدف هذه الاتفاقيات جميعها إلى حماية الحق في الإبداع في مجال مصنفات

التتنية المعلوماتية، ومنح المبتكر الحق في الاستغلال العادل والمشروع لعائدات هذه المنفات ضمن أطر وقواعد إدارية.

وفي التثريعات الداخلية للاول نجد أن أغلبية القوانين المتعلقة بحقوق المؤلف في معظم الدول على نوعين من طرق الحماية القانونية لحقوق الدؤلف ، أحدها مدني

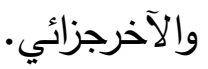

أما الوسائل الددنية فهي تمكن الدؤلف من اتخاذ الإجراءات اللازمة لدصادرة الصنفات المزورة أو الدقلدة وإتلافها ،أو وقف التعدي على المصنف، والمطالبة بالتعويض عن الضرر المادي والمعنوي الذي لحق بالمصنف أو بسمعة المؤلف('). ( (')طفي. محمد حسام: تأثير اتفاقية تربس على التشريعات العربية، ندوة الويبو بالتعاون مع الجامعة الأردنية، فبر اير

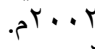

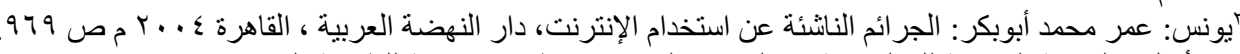

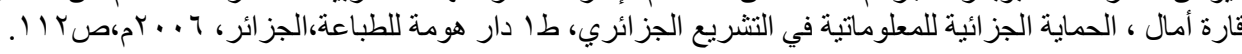
$\{\leqslant 90)$ 


$$
\text { r.r. · مجلة روح القوانين - العدد الثانى والتسعون - إصدار أكتوبر }
$$

أما الحماية الجزائية فقد تقتصر على الغرامة المالية أو إغلاق المؤسسة التي شاركت في ارتكاب أعمال التعدي على حقوق المؤلف، أو فرض عقوبة الحبس على كل من يخالف أحكام قوانين حقوق المؤلف أو يتعدى على تلك الحقوق('). كما تعطي القوانين للجهات القضائية صلاحية الأمر باتخاذ إجراءات و تدابير تحفظية مؤقتة فورية وفعالة لغرض الحيلولة دون حدوث تعدي على الحقوق المحمية و كذا لصون الأدلة ذات الصلة بالتعدي، وذلك بطلب من مالك الحقوق المتضرر أو ممثله حيث يجوز لمالك الحقوق المتضرر أن يطلب من الجهة القضائية المختصة اتخاذ التدابير التحفظية اللازمة لمنع الاعتداء الوشيك الوقوع على حقوقه، أو لوضع حد لكل مساس معاين مع طلب تعويض الضرر اللاحق به وكذا المطالبة بحجز الدعائم المقلدة و الإيرادات المتولدة عن الاستغلال غير المشروع للمصنف وحجز كل مؤلف تقني مستخدم لصنع الدعائم المقلدة. وفي النهاية فإن جميع وسائل الحماية القانونية تقوم على ما يلي: 
11 - - حماية الملكية الفكرية في الأمن السيبراني

1- اتخاذ تدابير تعتد الامن كعنصر ضروري في الانتاج، لاسيما ما يخص

البرامج والاجهزة المستخمة في تقنيات الاتصال.

r- اعتماد مبادىء خلقية للسلوك السييراني، على مثال خلفيات وأصول التعامل

القائمة في المجتمع التقليدي، وتكون بمثابة عقد اجتماعي، يؤسس لسلوك، يضمن سلامة الجماعة، وسلامة مواردها.

ז- وضع استراتيجية، وسياسة أمنية واضحة وملزمة، لكل المعنيين بصناعة المعلومات، وبادراة وسائل الاتصالات، والبنى التحتية، كما لاولئك المعنيين بصناعة ادوات وبرامج الاتصال، وخزن الدعلومات ومعالجتها. ع - أخذ جميع ابعاد الامن السيبراني، بعين الاعتبار ، لاى وضع اي استراتيجية او سياسة، بما في ذلك، حاجات المواطنين والمؤسسات، كما حقوقهم وواجباتهم، بحيث تأتي الخطة متكاملة، ومنسمة مع ما يمكن توقع الالتزام به، من قبل

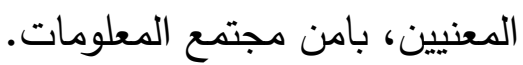


r. r · مجلة روح القوانين - العدد الثانى والتسعون - إصدار أكتوبر

الخاتمة - مان

وتتضمن أهم النتائج والتوصيات.

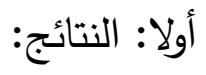

1- إن حماية الملكية الفكرية في مجال الفضاء السييراني أصبحت من الحاجات

الملحة، التي يفرضها واقع المعلومات الأمنية المعاصر .

ץ- تقوم حماية الملكية الفكرية في مجال الفضاء السيبراني على النشاط الذي يحمي أنواع المليكة الفكرية المرتبطة بالتقنيات الحديثة للاتصالات والمعلومات، مع ضمان الحد من الخسائر والأضرار الواقعة أو محتملة الوقوع. r- تقتضي حماية الملكية الفكرية في مجال الفضاء السيبراني بحث أهم الأساليب في مجال إدارة نظام امن المعلومات للوقوف على عوامل نجاحها والصعوبات والمعوقات التي تواجهها. وبناء بنية تحتية معلوماتية تكون قادرة على العمل بكفاءة وفاعلية. ع- العمل على تطوير الاوجه القانونية والتشريعية لتكون متوازنة مع التقدم التكنولوجي، ولتضمن الوقاية من مخاطر الاعتداء على المعلومات والتهيوء للحالات الطارئة ووضع الخطط اللازمة لمواجهتها. 
11

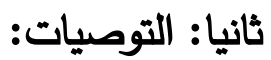

1- نهيب بالمنظم السعودي استصدار نظام خاص بحماية الملكية الفكرية في مجال الفضاء السييراني يتوافق مع طبيعة تلك الأعمال.

ץ- ضرورة تشجيع المبدعين على إنشاء برامج تتسم بالجدة والابتكار لحماية المعلوماتية وتحقيق الأمن السيبراني، والعمل على حفظ حقوق هؤلاء المبدعين. r- إدخال مادة حماية الملكية الفكرية في مجال الفضاء السيبراني لكليات الدراسات القضائية والأنظمة ليتم تدريسها حتى تكون لدى هؤلاء الطلاب الذين هم قضاة ومحامو المستقبل تصور كامل عن هذه المستجدات. ع - تأهيل الاجهزة القضائية المختصة، والثرطة القضائية، بحيث تتمكن من القيام بواجبها، في مجال ملاحقة ومحاكمة الدجرمين السيبرانيين. 0- إنشاء هيئات تحكيم وطنية، متخصصة في القضايا السيبرانية، وخدمات استشارات، مسبقة ولاحقة لاي نشاط الكتروني، يمكن لمن يرغب، اللجوء اليها. 
r. r · مجلة روح القوانين - العدد الثانى والتسعون - إصدار أكتوبر

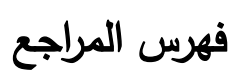

( ابراهيم. خالد ممدوح: أمن الجريمة الاكترونية، الدار الجامعية للنشر ^... بم،

$$
\text { الشوابكة. }
$$

r) إبراهيم: خالد مدوح: الجرائم المعلوماتية.

$$
\text { r) (بن فارس: مقاييس اللغة،جا (،. }
$$

ع) ابن منظور: محمد بن مكرم بن على، أبو الفضل، جمال الدين ابن منظور

$$
\text { الأنصاري الرويفعى الإفريقى، دار صادر - بيروت طץ § اء اهـ ج. ا. }
$$

0) أبو الحسين:أحمد بن فارس بن زكرياء القزويني الرازي، أبو الحسين: معجم مقاييس اللغة، تحقيق: عبد السلام محمد هارون، نشر دار الفكر 99 ا اهـ /9V9 ام. جه. 7) أبو العباس: أحمد بن محمد بن علي الفيومي ثم الحموي: المصباح المنير في

$$
\text { غريب الثرح الكبير، نشر : المكتبة العلمية - بيروت، ج؟. }
$$

V أبو عامر: محد زكي: دراسة علم الإجرام والعقاب، الدار الجامعية بيروت

$$
.01914
$$

^) أبو هيبة. نجوى: التوقيع الاكتروني، تعريفه مدى حجيته في الإثبات، دار

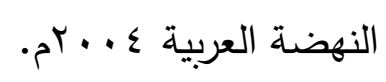

9) أحمد حسام طه تمام: جرائم الحاسب الآلي، دار النهضة العربية. 
11 - 11

• (1) احدد: هلالى عبدالاه: تفتيش نظم الحاسب الآلي وضمانات الدتهم المعلوماتى.

1') أحمد: هلالي عبد اللاه: اتفاقية بودابست لدكافحة جرائم المعلوماتية (معلقا

$$
\text { عليها )، طا دار النهضة العببية V...rم. }
$$

r r ا البثري: محمد الأمين: التحقيق في جرائم الحاسب الآلي، بحث مقدم إلى مؤتمر

القانون والكمبيوتز والإنترنت المنعقد في الفترة منن 1 - r مايو ... ب بكلية

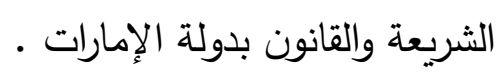

rا (1) تمام: أحمد حسن طه: الجرائم الناشئة عن استخدام الحاسب الآلي، دار النهضة

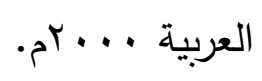

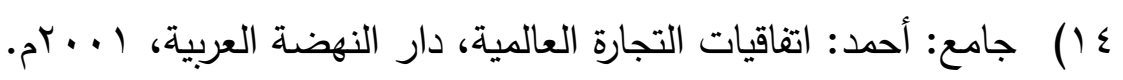

10) الجنيهي: منير محمد: جرائم الانترنت والحاسب الآلم ووسائل مكافحتها - دار

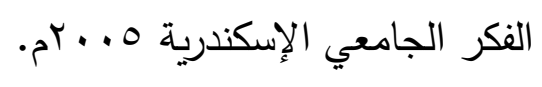

14) حجازي. عبد الفتاح بيومي ، جرائم الكمبيوتر والانترنت، دار النهضة العربية

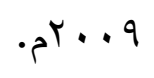

(IV حجازي. عبد الفتاح بيومي: التجارة الإلكترونية وحمايتها القانونية، الكتاب

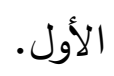


r. r. · مجلة روح القوانين - العدد الثانى والتسعون - إصدار أكتوبر

11) حجازي. عبد الفتاح بيومي: مكافحة جرائم الكمبيوتر والإنترنت في القانون

$$
\text { العربي النموذجي، دار الكتب القانونية V •. . ام. }
$$

19) حسن: سعيد عبد اللطيف: إثبات جرائم الكومبيوتر والجرائم المرتكبة عبر

$$
\text { الانترنت طا دار النهضة العربية } 999 \text { ام، القاهرة. }
$$

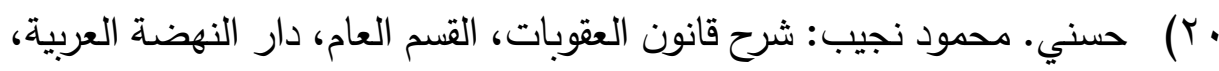

$$
.01919 / 7 \text { b }
$$

حسني: محمود نجيب: شرح قانون الإجراءات الجنائية ، الجزء الأول، طب (Y)

$$
\text { دار النهضة العربية، القاهرة } 911 \text { ام. }
$$

r T الحسيني: عمر الفاروق: تأملات في بعض صور الحماية الجنائية لبرامج الحاسب الآلي، مجلة المحاماة، س r| عدد نوفمبر/ديسمبر 9199.

rrr حماد: عادل حماد عثمان: حماية المعلومات في التشريع الجنائي السوداني.

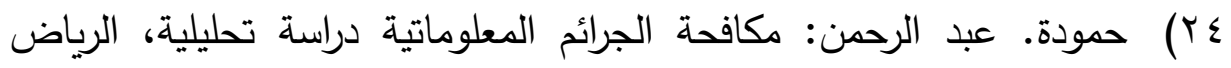

$$
\cdot p^{r} \cdot \cdot q
$$

Po ) خالد مددوح ابراهيم: الجرائم المعلوماتية. Tr) داود: حسن طاهر : جرائم نظم المعلومات، أكاديمية نايف العربية للعلوم الأمنية،

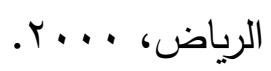


11 - 11

الرازي: زين الدين أبو عبد الله محدد بن أبي بكر بن عبد القادر الحنفي: مختار

الصحاح، تحقيق: يوسف الثيخ محمد، نشر الدكتبة العصرية - الدار النموذجية،

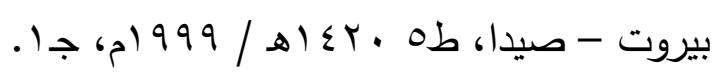

(YA رستم :هشام محمد فريد: قانون العقوبات ومخاطر تقنية المعلومات - مكتبة

$$
\text { الآلات الحديثة ب99 ام. }
$$

9 (Y9) رستم: هشام محمد فريد: الجوانب الإجرامية للجرائم المعلوماتية، مكتبة الآلات

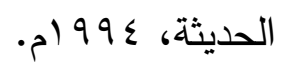

• ب) رمضان: عمر السعيد: شرح قانون العقوبات الاتحادية لدولة الإمارات العربية المتحدة - القسم الخاص، دار النهضة العربية، القاهرة ب19 ام.

(ب) رضنان: مدحت، جرائم الاعتداء على الأشخاص والإنترنت ، دار النهضة

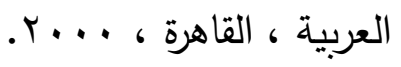

r الر) الرومي: محمد أمين: جرائم الكمبيوتر والانترنت، دار المطبوعات الجامعية

$$
\cdot r^{r} \cdot \varepsilon
$$

بr) الزحيلي. وهبة: بطاقات الائتمان، بحث بمجلة مجمع الفقه الإسلامي، جه 1،

$$
\text { عددץ. }
$$

$$
\text { ع (ب) الزمخشري: أساس البلاغة، جـا. }
$$


r. r. · مجلة روح القوانين - العدد الثانى والتسعون - إصدار أكتوبر

مr) زين الدين: بلال أمين: جرائم نظم المعـالجـة الآليـة للبيانـات، دار الفكر

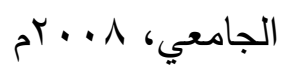

جبا) سالم. عمر : الحماية الجنائية لبطاقات الوفاء، دار النهضة العربية 990 ام.

(TV ) السعيد: كامل: شرح الأحكام العامة في قانون العقوبات الأردني والقانون المقارن

$$
\text { طץ دارالفكر للنشر والتوزيع - عمان ra ام. }
$$

ر^r) سلامة: مأمون محمد: الإجراءات الجنائية في التشريع الليبي ، الجزء الثاني،

$$
\text { طr منشورات المكتبة الوطنية، بنغازي ، .... }
$$

9 سبليم د طارق عبد الوهاب: الجرائم المرتكبة بواسطة الانترنت وسيل مكافحتها،

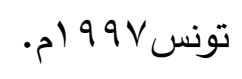

• • السنهوري: عبد الرازق: الوسيط في شرح القانون المدني - حق الملكية-، دار

$$
\text { إحياء التراث العربي، بيروت لبنان، جـ. }
$$

جبور : منى الأشقر: الأمن السيبراني: التحديات ومستلزمات المواجهة، من منشورات جامعة الدول العربية، المركز العربي للبحوث القانونية والقضائية، اللقاء السنوي الأول للمختصين في أمن وسلامة الفضاء السيبرانيبيروت V - Y أغسطس (آب) r Y.r، وانظر: مجلة محطات، مقال منشور بتاريخ https://www.mahat.net : 19/\%/9 • ب rم، على الرابط 
| 11 - حماية الملكية الفكرية في الأمن السيبراني

r T أثايع: خالد: الأمن السييراني، مفهومه، وخصائصه، وسياساته، دار العالمية،

$$
\text { الأولى، . •؛ أه. }
$$

شبير : محمد عثمان: المدخل إلى فقه المعاملات المالية، دار النفائس، الطبعة

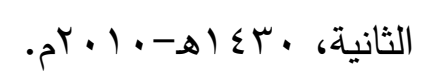

r أ) الثوا. محمد سامي: ثورة المعلومات وانعكاساتها على قانون العقوبات.

§ §) الصغير . جميل عبد الباقي: الانترنت والقانون الجنائي ، دار النهضة العربية

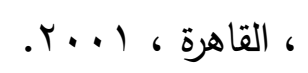

0؛) الصغير . جميل عبد الباقي: الانترنت والقانون الجنائي، دار النهضة العربية

$$
\text { pror }
$$

4؟) الصغير • جميل عبد الباقي: الجرائم الناشئة عن استخدام الحاسب الآلي، دار

$$
\text { النهضة العربية ا..بץ. }
$$

(EV ) العبادي: عبد السلام: الملكية في الشريعة الإنلامية، مكتبة الأقصى، عمان،

$$
\begin{aligned}
& \text {. I T PVV } \\
& \text { 1§) عبد الحميد. ثروت: التوقيع الاكتروني. }
\end{aligned}
$$

9 §) عبد الرحمن: محمد جلال: الجرائم الاليكترونية، طا مكتبة القانون والاقتصاد،

$$
\text { . }
$$


r. r. • مجلة روح القوانين - العدد الثانى والتسعون - إصدار أكتوبر

•) عثمان. عبد الحكيم: أحكام البطاقات الائمانية في القانون والآراء الفقهية

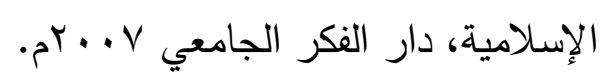

10) العثماني: محمد تقي: بيع الحقوق المجردة: بحوث الدورة الخامسة لمؤتمر

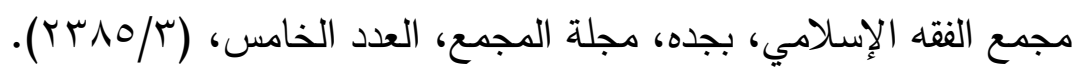

(Or عرب، يونس. ثلاث طوائف لجرائم الكمبيوتر وثلاث مجموعات تشريعية

لمواجتها، مجلة حماية الملكية الفكرية، ع·• ب، الربع الثاني، ب99 19،

ror) العريان: محمد علي: الجرائم المعلوماتية - كلية الحقوق - جامعة الإسكندرية

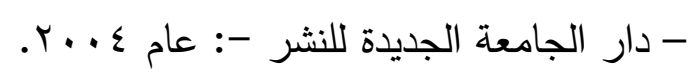

§o) علاء الدين، أبو بكر بن مسعود بن أحمد الكاساني الحنفي: بدائع الصنائع في

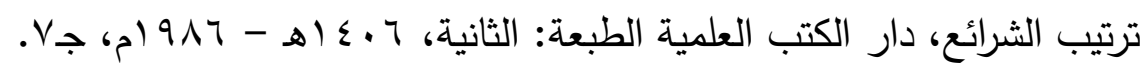

$$
\text { 00) علي بن هادية وآخرون، القاموس الجديد الألفبائي. }
$$

107) علي. عبد الله حسين: حماية المعلومات المخزنة على الحاسب الآلي، رسالة

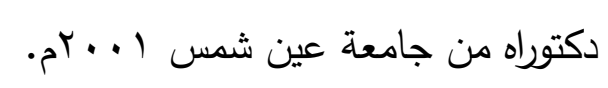

(OV ) ملي: محد محرم محمد: جريمة النصب و الإحتيال والتجارة الالكترونية القاهرة 
11 - حماية الملكية الفكرية في الأمن السيبراني

O1 موض: محمد محي الدين: مشكلات السياسة الجنائية المعاصرة في جرائم

نظم المعلومات ( الكمبيوتر ) ، ورقة عمل مقدمة إلى المؤتمر السادس للجمعية

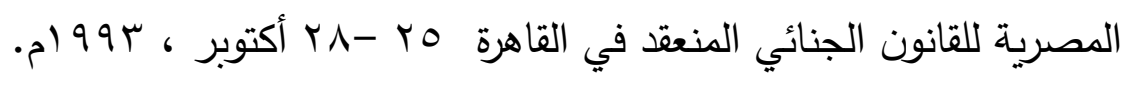

ه9 ) فكري. أيمن عبد الله: جرائم نظم المعلومات دراسة مقارنة، دار الجامعة

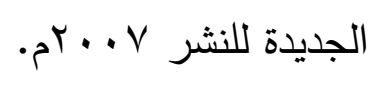

• 7) الفيروزآبادي: مجد الدين أبو طاهر محمد بن يعقوب الفيروزآبادى، تحقيق:

مكتب تحقيق التراث في مؤسسة الرسالةبإشراف: محمد نعيم العرقُُوسي،

نشر : مؤسسة الرسالة للطباعة والنشر والتوزيع، بيروت - لبنان طم ج؟؟ 1

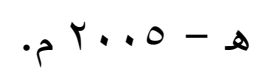

(T) قارة أمال ، الحماية الجزائية للمعلوماتية في التشريع الجزائري، طا دار هومة

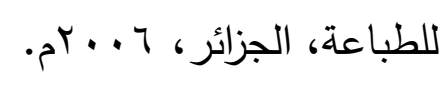

بآ) قدري: كامل: الحماية الجنائية للملكية الفكرية، رسالة دكتوراه، جامعة القاهرة،

$$
\text { كلية الحقوق، قسم القانون الجنائي، ـ ا ـ كم. }
$$


r.r. · مجلة روح القوانين - العدد الثانى والتسعون - إصدار أكتوبر

rا7) القرافي: أبو العباس شهاب الدين أحمد بن إدريس بن عبد الرحمن المالكي

الثهير بالقرافي: أنوار البروق في أنواء الفروق، نشر عالم الكتب، د.طان

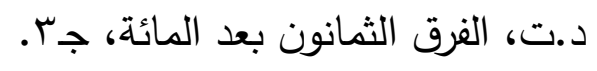

§ آ) قشقوش. هدى: جرائم الحاسب الالكتروني، مرجع سابق.

07 (7نديل. سعيد السيد: التوقيع الالكتروني، ماهيته وصوره وحجيته في الإثبات

بين التدويل والاقتباس، دار الجامعة الجديدة للنشر ع . . بم.

77) قورة. نائلة عادل: جرائم الحاسب الآلي الاقتصادية، مرجع سابق.

(TV لحرش: أسعد المحاسن: الملكية الفكرية بين تثجيع الابتكار وتحريم

الاحتكار، منشور بموقع https://platform.almanhal.com، بتاريخ

. $) \leqslant \leqslant 1 / \wedge / 0$

14 لطفي. محمد حسام محمود: الحماية القانونية لبرامج الحاسب الإكترونية،

دار الثقافة للطباعة والنشر 9Nv ام.

79) لطفي. محمد حسام: تأثير اتفاقية تربس على التشريعات العربية، ندوة الويبو

بالتعاون مع الجامعة الأردنية، فبراير r +. rم.

) محمد أمين: جرائم الحاسوب والانترنت.

$(0.1)$ 
11

محمد: فتحي عبد الهادي. أخلاقيات المعلومات في مراكز المعلومات (V)

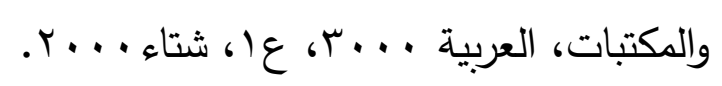

(VY ) محمود: عمر: الجرائم المعلوماتية والإكترونية ،.

(VT) مختار : أحمد: معجم اللغة العربية المعاصرة، عالم الكتب الطبعة: الأولى،

$$
\text { r }
$$

ع المري. عايض راشد: مدى حجية الوسائل التكنولوجية الحديثة في إثبات

$$
\text { العقود التجارية، رسالة دكتوراه من حقوق القاهرة } 9191 \text { م. }
$$

Po المري: راشد محمد: الجرائم الإكترونية في ظل الفكر الجنائي المعاصر

$$
\text { دراسة مقارنة، دار النهضة العربية م1 ا• rم. }
$$

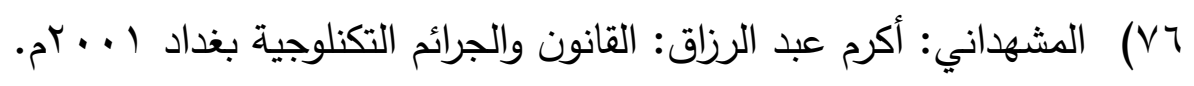

(VV ) المغايرة: علاء الدين منصور : الأوجه الحديثة للجرائم المعلوماتية، رسالة

$$
\text { ماجستير قدمت لجامعة الحكمة بيروت .... Tم. }
$$

(VA مكي: محمد عبد الحميد: الاحتيال في قانون العقوبات - دراسة مقارنة -

$$
\text { رسالة دكتوراه - جامعة القاهرة، } 911 \text { (م. }
$$


r. r. • مجلة روح القوانين - العدد الثانى والتسعون - إصدار أكتوبر

(V9 المناعسة: أسامة أحمد: جرائم الحاسب الآلي والإنترنت، دراسة تحليلية

$$
\text { مقارنة، طا دار وائل للنشر عمان الأردن، +. بץ. }
$$

•) المهيري. خالد: جرائم الكمبيوتر والانترنت والتجارة الإلكترونية، طץ /

$$
\text { bros }
$$

(1) النشمي: عجيل جاسم: الحقوق المعنوية: بيع الاسم التجاري، مجلة البحوث

$$
\text { الإسلامية، مكة، مجمع الفقه الإسلامي. }
$$

r^) يوسف. أمير فرج: المحاكم الإكترونية المعلوماتية والتقاضي الالكتروني.

r^) يونس: عمر محمد أبوبكر: الجرائم الناشئة عن استخدام الإنترنت، دار

$$
\text { النهضة العربية ، القاهرة ع . .. م م. }
$$

